YINPING LIU

\title{
Glossário Terminológico de Comércio Exterior Chinês/Português
}

Dissertação de Mestrado

Programa de Pós-Graduação em

Semiótica e Lingüística Geral

Departamento de Lingüística, Faculdade

de Filosofia, Letras e Ciências Humanas

da Universidade de São Paulo

Orientador: Francis Henrik Aubert

São Paulo, maio de 2006 


\section{SUMÁRIO}

Tópico

Página

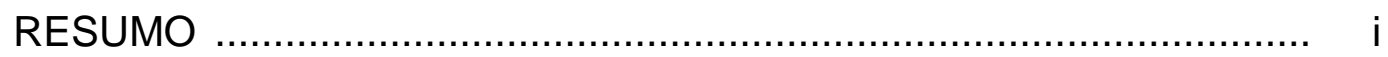

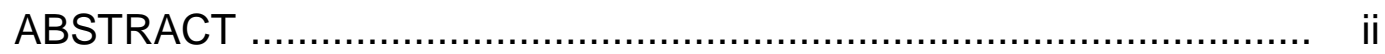

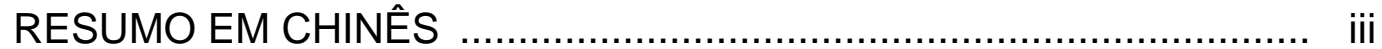

AGRADECIMENTOS ............................................................... iv

I. INTRODUÇÃO .......................................................................... 1

1.1 Justificativa do tema ........................................................ 1

1.2 História e contextualização ................................................. 3

1.2.1 Relações entre a China e a Lusofonia - breve histórico ... 3

1.2.2 Relações entre a China e o Brasil .................................. 6

1.2.2.1 Relações culturais ........................................... 6

1.2.2.2 Relações comerciais ......................................... 15

1.3 Dicionários de chinês e português ........................................ 20

II. FUNDAMENTOS TEÓRICOS …............................................... 22

2.1. Aspectos históricos e conceptuais da Terminologia ................ 22

2.1.1 Definições básicas ..................................................... 22

2.1.2 História da Terminologia ............................................ 28

2.2 Teoria da Terminologia ................................................... 38

2.2.1 Principais teorias fundadoras …………...................... 38

2.2.2 Objetos de estudos da Terminologia ............................. 41

2.2.3 Aplicações dos conhecimentos terminológicos ................ 42

2.3 Modalidades de trabalho terminológico ................................. 44

2.3.1 Tipologia das obras lexicológicas e terminológicas .......... 44

2.3.2 Componentes estruturais dos repertórios ....................... 48

III. METODOLOGIA DO TRABALHO TERMINOLÓGICO ................... 58

3.1 Planejamento de projetos terminográficos …......................... 58

3.1.1 Objetivos e público-alvo ........................................... 58 
3.1.2 Delimitação de sub-área ……..................................... 58

3.1.3 Trabalhos de preparação …….................................... 60

3.2 Execução do projeto de glossário de comércio exterior ............ 60

3.2.1 Estabelecimento do corpus e coleta das unidades especializadas ...................................................... 60

3.2.2 Registro dos dados em fichas eletrônicas ....................... 61

3.3 Estrutura do glossário ...................................................... 67

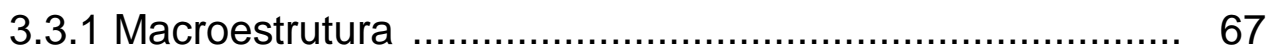

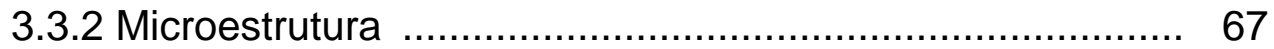

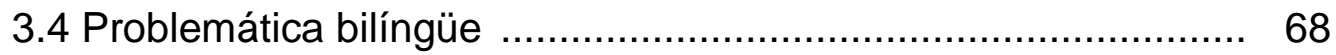

3.4.1 Equivalência e observações ......................................... 68

3.4.2 Solução para lacunas de equivalência ............................ 69

3.5 Problemática da influência dos empréstimos do inglês ............ 70

3.5.1 Influência do inglês no chinês e no português ................. 70

3.5.2 Influência do inglês na área de comércio exterior ............. 72

3.5.3 Aspectos potencialmente negativos e prejudiciais da influência do inglês sobre a comunicação chinês/português ..... 72

3.6 Consulta aos especialistas ............................................... 73

IV. GLOSSÁRIO TERMINOLÓGICO DE COMÉRCIO EXTERIOR ...... 75

4.1 Apresentação .............................................................. 75

4.2 Índice remissivo e glossário chinês/português ........................ 76

4.3 Índice remissivo e glossário português/chinês ......................... 97

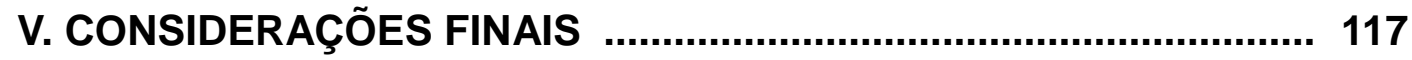

VI. REFERÊNCIAS BIBLIOGRÁFICAS ........................................... 119

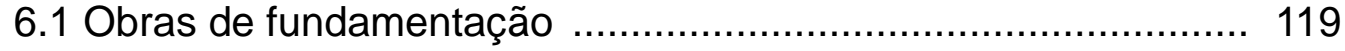

6.2 Obras especializadas em comércio exterior .......................... 120

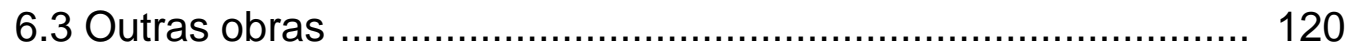

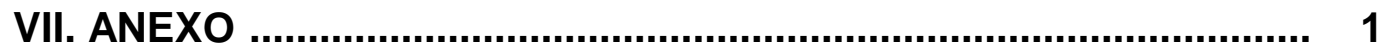

7.1 Páginas de referência de dicionários português/chinês ............ 1

7.2 Documentos de comércio exterior ............................................. 8 



\title{
RESUMO
}

\begin{abstract}
A dissertação "Glossário Terminológico de Comércio Exterior" Chinês/Português/Chinês tem por objetivo elaborar uma pesquisa terminográfica bilíngüe das unidades de conhecimento especializado relacionadas à área de comércio exterior relevantes para a relação Brasil-China, por meio da organização dessas unidades em um glossário terminológico.

Inicialmente faz-se uma revisão da história cultural e comercial entre o mundo lusófono e o chinês com o objetivo de justificar a demanda de um trabalho terminológico de comércio exterior entre o Brasil e a China. A seguir, apresenta-se uma introdução à história e à teoria fundamental da Terminologia. Aplicando-se os métodos da terminologia descritiva, coletaram-se e registraram-se as unidades especializadas constantes de documentos comumente empregados no comércio exterior. A parte final deste trabalho compreende um glossário organizado consoante os dados constantes das fichas terminológicas, com cerca de 120 termos entre chinês-português e português-chinês.
\end{abstract}

Palavras-chave:

Terminologia, Comércio Exterior, China, Chinês, Glossário 


\section{ABSTRACT}

The thesis "Terminological Glossary of International Trade (Chinese/Portuguese/Chinese)" purports to conduct a bilingual terminological survey of international trade terms relevant to Chinese-Brazilian relations, and to organize them into a terminological glossary.

The first part of thesis proposes a review of the 500 years of history of cultural and commercial interchanges between speakers of Portuguese and of Chinese, so as to justify the need for a bilingual terminological glossary in support of the Brazil-China international trade. There follows a brief introduction about the history and the fundamental theory of Terminology. With the assistance of the methods proposed for descriptive terminology, the special purpose terms found in documents commonly employed in international trade were collected and recorded. The final part of this thesis is the glossary itself, derived from the data recorded in the terminological file cards, containing approx. 120 terms

Key words:

Terminology, Glossary, China, Chinese, International Trade 


\section{RESUMO EM CHINÊS}

6

9

500 


\section{AGRADECIMENTOS}

Ao Prof. Dr. Francis Henrik Aubert, meu orientador, por ter-me aceitado como sua orientanda de mestrado, pela orientação com grande paciência no meu estudo de lingüística, pelas revisões e correções indispensáveis do meu relatório do Exame de Qualificação e da Dissertação, e pelo suporte de demais assuntos acadêmicos.

A minha família, a minha mãe, Shen Aiying; ao meu pai Liu Jindou; e aos meus avós, pela criação e educação que me conduziram até este caminho de grande realização da minha vida.

À Prof ${ }^{a}$. Dr ${ }^{\mathrm{a}}$. Ana Müller, pela coordenação e atenção no meu curso de mestrado.

Aos $\operatorname{Prof}^{\mathrm{a}}$. Dr ${ }^{\mathrm{a}}$. Ieda Maria Alves, $\operatorname{Prof}^{\mathrm{a}}$. Dr ${ }^{\mathrm{a}}$. Irenilde Pereira dos Santos, $\operatorname{Prof}^{\mathrm{a}}$. $\mathrm{Dr}^{\mathrm{a}}$. Stella Esther Ortweiler Tagnin e Prof. Dr. Fernando Augusto Albuquerque Mourão, pelos ensino e orientação nas disciplinas de estudos lingüísticos e históricos, o que permitiu a minha aprendizagem das teorias e dos conhecimentos importantes para meu projeto de mestrado e a própria dissertação.

À CAPES - Coordenação de Aperfeiçoamento de Pessoal de Nível Superior, pela concessão da Bolsa de mestrado e auxílio ao meu estudo e à minha vida no Brasil.

Aos secretários do Departamento de Lingüística, à Érica, ao Robson, ao Ben Hur, pelos suporte e ajuda durante o meu estudo de dois anos e meio no departamento.

Ao Serviço de Pós-Graduação, a Chefe Regina Celi Sant'Ana e aos colegas Júlio, Leonardo, Miguéias, José, João, entre outros, pelos auxílio, compreensão e paciência para uma aluna estrangeira.

Aos meus amigos Nize Paraguassu, Annick Arnoult, Luana Maria Vieira de Siqueira, Marcus Avelar, que me acompanham nestes dois anos e meio, me apoiam e ajudam a viver em São Paulo, e me deram força para terminar o curso.

Ao Prof. Sylvio R. G. Horta, pela prestação de informação da história do curso da língua chinesa na Universidade de São Paulo.

A Cui Zheng, Zou Wenyu e Sónia Bochnia, pelas revisões e sugestões para o glossário de comércio exterior da minha dissertação.

Aos meus professores da Universidade de Línguas Estrangeiras de Pequim, Prof. Zhou Hanjun, Prof. Ye Zhiliang, Prof. Manuel Pinho e Prof. Wang Fushan (In memorium), e da Universidade de Macau, Profa . Leonor Seabra, Prof. Raúl Pissarra e Prof. Luís, pela introdução e ensino da língua portuguesa de 1998 a 2002. A Maria 
Lúcia Verdi, adido cultural da Embaixada do Brasil em Pequim, pela assistência na solicitação a Bolsa do PEC-PG da CAPES. 


\section{INTRODUÇÃO}

\subsection{Justificativa do tema}

Com a rápida expansão e intensificação das relações culturais e comerciais diretas entre o Brasil e a China, um dicionário bilíngüe de chinês (mandarim) e português do Brasil (PB) torna-se uma necessidade cada vez mais premente. No momento, existe apenas dois dicionários gerais de português europeu (PE) na China. Por outro lado, enquanto bolsista de CAPES no programa de convênio de educação superior entre o Brasil e a China, considero ser da maior relevância que o tema de meu trabalho de mestrado oferecesse uma contribuição relevante à comunicação recíproca entre dois países.

Dentre as diversas áreas especializadas, o comércio exterior é uma das áreas mais importantes e indispensáveis e que se sobrepõe a diversas áreas técnicas, sempre que os intercâmbios nestas áreas envolvam operações de exportação e de importação. Por este fator, escolhi fazer um glossário nesta área, com o título "Glossário Terminológico de Comércio Exterior Chinês/Português/Chinês".

O presente projeto baseia-se nos documentos utilizados no processo de importação e exportação. Recolhi os termos mais comuns e essenciais da área de comércio exterior, deixando para um glossário mais rico e detalhado no futuro os demais termos relacionados à teoria de comércio exterior, à classificação de mercadorias, a transações financeiras, e à legislação comercial. 
Tal como desenvolvido aqui, o projeto compreende os seguintes passos: apresentação de uma base teórica em terminologia ligada ao fazer terminográfico; coleta e identifição dos termos específicos dos documentos de comérico exterior de língua portuguesa e chinesa, tais como, conhecimento de embarque, certificado de inspeção sanitária, nota fiscal, fatura pro-forma, fatura comercial, declaração de importação e exportação, etc.; verificação do significado de termos às obras de língua portuguesa e chinesa de comércio exterior, inclusive em dicionários especializados monolíngües e obras similares; definição destes termos de acordo com os preceitos metodológicos da terminologia; elaboração dos verbetes do glossário; e consulta dos verbetes aos especialistas da área em questão.

O célebre lexicógrafo inglês, Samuel Johnson (1709 - 1784), que dedicou toda a sua vida à compilação do Dicionário da Língua Inglesa, proferiu uma máxima famosa, baseando-se nas sua próprias experiências: "Os dicionários são como relógios: o pior é melhor do que aquele que não existe; do melhor não se pode esperar uma precisão perfeita." No mundo de hoje, mais de um bilhão e trezentos milhões de pessoas falam chinês e cerca de duzentos milhões de pessoas falam português. Espero que este glossário seja útil para comunicação melhor entre eles na área comercial, e que possa servir de estímulo para novos estudos terminológicos entre o chinês e o português. 


\subsection{História e contextualização}

\subsubsection{Relações entre a China e a Lusofonia - breve histórico}

As relações entre o português e o chinês remontam a centenas de anos atrás, desde que os navegadores portugueses aportaram em Macau, aproximadamente à mesma época em que Portugal tomava posse do que viria a ser o Brasil. Em 1498, Vasco da Gama abriu a rota oriental da Europa para a Índia, dobrando o Cabo da Boa Esperança e adentrando o Oceano Índico. Em 22 de abril de 1500, Pedro Álvares Cabral ancora diante do que hoje é Cabrália e Porto Seguro, no Brasil. Em setembro de 1517, os portugueses chegaram a Guangzhou (uma cidade do litoral sul da China), mas somente em 1553 obtêm permissão para constituírem um estabelecimento permanente em Macau. Desde então, as rotas comerciais marítimas definem um espaço privilegiado das relações sino-lusófonas.

Macau, uma pequena vila de pescadores próxima a Guangzhou começou a funcionar como um porto mediador para o comércio entre os mundos oriental e ocidental. Os portugueses participavam, duas vezes por ano, na primavera e no verão, das feiras de comércio da província Guangdong da China e compravam mercadorias tais como seda, cerâmica e chá. Em seguida, transportavam a mercadoria para Macau, e posteriormente revendiam-na no Japão, no Sudeste da Ásia, na Europa e na América. As naus mercantes ocidentais deviam solicitar licença para entrar no porto de Guangzhou, pagar impostos aduaneiros e empregar chineses para desenvolver o comércio na China. Por um período de 280 anos entre os séculos XVI e XIX, todas as rotas comerciais entre China e os outros países do mundo passavam obrigatoriamente pelo porto de Macau. ${ }^{1}$

As rotas eram:

Guangzhou - Macau - Goa - Lisboa;

\footnotetext{
${ }^{1}$ HUANG, Q. C. A Posição Dominante da China na Globalização Mundial - do Meio de Século XVI ao Começo de Século XIX. Guangzhou, Zhongshan Universidade/Faculdade da História, 2004.
} 
Guangzhou - Macau - Japão;

Guangzhou - Macau - Manila - América Latina: a rota mais longa da época entre o Ocidente e o Oriente, desde 1575. Na América Latina, os navios chegavam primeiramente a Acapulco no México e Lima no Peru, e depois nevegavam para o sul, contornando o continente no Estreito de Magalhães, até atingirem o Brasil. As mercadorias vindas da China eram sedas, tecidos, cerâmicas, panelas de ferro e remédios da medicina tradicional chinesa; as mercadorias transportadas de volta para Ásia eram prata, pau-brasil, mel e propólis, tinta vermelha do México, etc.;

Guangzhou - Macau - Timor;

Guangzhou - Macau - Nova lorque

Guangzhou - Macau - Rússia

Guangzhou - Macau - Austrália

Além do comércio desenvolvido pelos mercantes portugueses, os missionários, jesuítas e de outros, promoviam também a comunicação entre a China e a Europa. Entre eles, o mais conhecido era o missionário italiano Matteo Ricci (1552 1610). Ele entrou na China através de Goa e Macau e chegou em Pequim (Beijing) em 1583, mais tarde, conseguiu a permissão para pregar a religião. Ele adaptou bem às tradições culturais chinesas e integrou a ideologia católica à filosofia de Confúcio. Ele foi também a primeira pessoa que introduziu os pensamentos de Confúcio no Ocidente. Através dos contatos com inteletuais chineses, ele introduziu também os conhecimentos científicos ocidentais na China, o que promoveu a difusão da ciência natural ocidental.

A Guerra do Ópio de 1840 trouxe profundas alterações a este quadro. Com a elevação do poder do Reino Unido e a decadência de Portugal e da Espanha, Hong Kong, colônia do Reino Unido, nessa época, substituiu Macau e tornou-se o porto mais importante e ocupado no comércio ocidental e oriental. Com isso, paulatinamente, a comunicação direta português/chinês passa a ser substituída pela comunicação mediada por outrs línguas, veículos de culturas maior relevân- 
cia geopolítica (e com poder maior de influenciar/intervir nas relações da China com o restante do mundo), terminando por desembocar na universalização do inglês, como língua prioritária de comunicação entre o ocidente e o oriente. Como se verá no item que se segue, porém, a prioridade do inglês não eliminou a comunicação direta português/chinês, que hoje, na minha percepção, passa por uma forte reativação.

\section{Língua portuguesa em Macau}

A administração de Macau pelos portugueses durou até 1999. Segundo números estatísticos, até abril de 2002, em Macau tinha 430 mil habitantes, 20 a 30 mil deles eram descendentes de portugueses e chineses, ou seja, macaences. $O$ Governo do Território de Macau divulgava a língua portuguesa em escolas primárias e colégios como disciplina obrigatória, porém, os habitantes de Macau falavam mais cantonês (língua predominante da Província de Guangdong) do que o português.

O Instituto Camões e o Instituto Português do Oriente (doravante IPOR) (www.ipor.org) dedicam-se à difusão da Língua e Cultura Portuguesa na Ásia.

O Instituto Português do Oriente foi estabelecido em 19 de setembro de 1989, e tem por finalidades preservar e difundir a língua e a cultura portuguesa no Oriente e promover o diálogo intercultural entre os portugueses e os povos do Oriente. Assume a responsabilidade de planejar atividades culturais e diplomáticas e assegura a coordenação administrativa dos Leitorados e Cursos de Português em universidades da Ásia, coordena a atribuição de prémios, bolsas e subsídios atribuídos pelo IPOR, bem como a execução do programa de atividades culturais em Macau.

Na parte do ensino da língua portuguesa na Ásia, o IPOR coordena as atividades da rede de Leitorados e Cursos de Português na Coreia do Sul, Filipinas, 
Indonésias, Japão, Malásia, República Popular da China, Tailândia e Vietname. Organiza Curso de Verão de Língua Portuguesa com vários níveis na Universidade de Macau. O curso é aberto para interessados de países asiáticos. Além disso, o instituto apoia os Cursos de Português ministrados nos Centros Culturais de Bangkok, Pequim (Beijing), Tóquio e Malaca, através da oferta de material bibliográfico e apoio didático. Tanto os alunos quanto os professores de língua portuguesa podem concorrer a bolsas de estudo para cursos em Macau e em Portugal.

Podemos observar que nos 500 anos de relação entre a China e o Brasil, o português europeu e o inglês foram as principais línguas responsáveis pela comunicação.

Nas universidades de línguas estrangeiras da China, os alunos especializados em língua portuguesa aprendem no geral o português europeu que é diferente do português brasileiro. Hoje, já existem professores brasileiros em algumas universidades. Desse modo, espera-se que as relações entre o Brasil e a China possam beneficiar-se desses contatos mais diretos .

\subsubsection{História e relacões sócio-econômica entre China e Brasil}

\subsubsection{Relações culturais - 30 anos de intercâmbio cultural}

Em 2004, o Brasil e a China completaram 30 anos do restabelecimento de relações diplomáticas. Ao longo desses últimos 30 anos, o cinema, a literatura, a televisão, as exposições de arte e a música vêm criando e consolidando laços culturais entre o Brasil e a China. Ambas as culturas conseguiram sucessos notáveis nesses campos, inclusive com reconhecimento internacional e, em especial a partir de 2003, os dois países intensificaram seus intercâmbios diretos com as várias exposições e eventos de arte.

Segundo informação cedida pela Seção Cultural da Embaixada da China, os últimos grupos chineses que vieram ao Brasil antes de interrupção nas relações 
diplomáticas foram o Grupo de Arte e o Circo de Chongqing, nos anos 50. Em novembro de 1978, a visita ao Brasil do Circo de Wuhan, com 50 integrantes, marcou a retomada dos contatos artíscicos sino-brasileiros. Em 1985, o embaixador chinês no Brasil, Tao Dazhao, assinou com o Ministério das Relações Exteriores um acordo de cooperação educacional e cultural, o que representou um novo passo na intensificação do intercâmbio. Em abril de 1991, os governos dos dois países articularam a primeira reunião da Comissão Mista Cultural Sino-Brasileira. Os acordos estabelecidos nessas reuniões estão em vigor até hoje, pois são renovados periodicamente.

Em 2003, ocorreram cinco visitas de delegações dos dois países para implementar acordos nas áreas de cultura e esportes. Em janeiro, o vice-reitor da Universidade de Pequim, Wang Yidao, visitou Brasil para promover intercâmbios acadêmicos (inclusive de docentes) com instituições brasileiras. No mês seguinte, o ministro da Administração Geral de Radiodifusão e Televisão, Xu Guangchu, chegou no Brasil para assinar um protocolo de cooperação nas áreas de televisão com a estatal Radiobrás. Em março, o vice-primeiro-ministro da Cultura, Zheng Xinmiao, participou da inauguração da exposição Cinco Mil Anos de Civilização: Relíquias de Shanxi e os Guerreiros de Xian, na Oca do Parque Ibirapuera, em São Paulo.

\subsection{Cinema}

Nos últimos anos, o cinema brasileiro produziu vários filmes bem conhecidos, tais como Central do Brasil, Cidade de Deus, O Quatrilho etc. O Brasil concorreu ao prémio de melhor filme estrangeiro do Oscar com $O$ Quatrilho e Central do Brasil. O último ganhou em 1999 o Urso de Ouro em Berlim e levou um total de 1,5 milhão de espectadores aos cinemas somente em 1999.

No mesmo período na China, o diretor chinês Ang Lee, de Taiwan, ganhou o Oscar de melhor diretor em 2006 com seu filme "Brokeback Mountain". Em 2001, 
a China havia conquistado o Oscar pela primeira vez representado por Tan Dun, com a trilha sonora do filme O Tigre e o Dragão. 10 anos atrás, em 1988, o diretor Zhang Yimou ganhou o Urso de Ouro em Berlim e o Tucano de Ouro no FestRio com o filme O Sorgo Vermelho. Ele havia concorrido em 1991 e 1992 ao Oscar de melhor filme estrangeiro com Amor e Sedução e Lanternas Vermelhas. Outro diretor chinês Chen Kaige, ganhou em 1985 os festivais de Londres, Montreal e Hong Kong com o filme Terra Amarela.

No ano passado, no começo de novembro, ocorreu a $29^{\text {a }}$ Mostra BR de Cinema - Mostra Internacional de Cinema em São Paulo. Cinco filmes chineses integraram a programação.

\subsection{Exposições}

Nos últimos anos, vieram da China muitas exposições variadas. Em 2003, teve lugar a exposição das mostras Tesouros Artísticos da China Antiga e Pintura Contemporânea da China, ambas no Museu da Casa Brasileira, em São Paulo. O curador Cláudio Barbosa disse: "Foi uma surpresa. Mesmo com a minha formação, nunca tinha tido muito contato com a arte chinesa. A parte oriental é muito reduzida na formação acadêmica brasileira". Entre as peças artísticas, havia 86 reproduções fiéis de artefatos fabricados entre 1600 a.C e o século XVIII - vasiIhas, máscaras e aparatos bélicos das dinastia Shang, Han do Oeste, Sui e Yuan.

Durante o período da exposição Guerreiros de Xian na Oca, no parque Ibirapuera, mais de 800 mil pessoas visitaram os soldados de terracota. Segundo a primeira-secretária da Seção Cultural da Embaixada da China no Brasil, Lu Aiting, entre as peças que vieram para o Brasil havia algumas que são difíceis de serem vistas até na China, por conta de sua importância para a cultura local. "Algumas nunca haviam saído do país, o que demonstra o apreço dos chineses pelo Brasil", disse. Mas há a contrapartida: "Durante a visita do presidente Lula à China, em maio de 2004, igualmente a exposição de artigos indígenas brasileiros no Palácio 
Imperial de Pequim atraiu milhares de chineses", acrescentou Lu.

Em novembro de 2004, veio ao Brasil um grupo de música e de dança que representava a tradição de várias províncias chineses.

Na área de música, o Brasil é conhecido na China pelo samba e pela bossa nova.

\subsection{Culinária}

Na culinária, a influência chinesa no Brasil foi grande, e começou já no início da imigração. Nas grandes cidades, entretanto, o número de restaurantes de cozinha chinesa só se tornou expressivo a partir do início dos anos 90. Hoje, estimase que somente em São Paulo haja mais de cem deles. Não há praticamente um shopping da cidade que não tenha comida expressa chinesa. Pratos como o frango xadrez, o rolinho "primavera" e o pato de Pequim se tornaram muito populares no Brasil, principalmente nos grandes centros, e começam a se fazer presentes, também, nas cidades médias.

\subsection{Língua}

O ensino de língua portuguesa na China começou nos anos 60, os alunos chineses do jornalista Jayme Martins na Universidade de Línguas Estrangeiras de Pequim passaram a traduzir autores clássicos brasileiros como Machado de Assis e Guimarães Rosa, e assim conheceram escritores e personagens de um distante país tropical, que, cada vez mais, começava a se tornar conhecido na China. Dos anos 60 a ano 2002, só haviam duas universidades que ensinavam o português de Portugal como curso de graduação, a Universidade de Línguas Estrangeiras de Pequim e a Universidade de Estudos Internacionais de Shanghai. O curso de

português oferecido por essas instituições recebe alunos a cada dois anos. Nessas 3 décadas, foram formados cerca de 400 alunos. Em 2002 e 2005, mais duas 
universidades abriram o curso de graduação da língua portuguesa, as quais foram Universidade de Comunicações da China e Universidade de Estudos Internacionais de Pequim. Desde 2002, a Universidade de Línguas Estrangeiras de Pequim passou a receber alunos novos todo ano. Desse modo, registra-se um claro incremento no número de chineses que dominam a língua portuguesa. De 1996 a 2006, os números de alunos formados e ingressantes dessas universidades são seguinte: 112 formados e 159 ingressantes na Universidade de Línguas Estrangeiras de Pequim (curso estabelecido em 1962), 45 formados e 65 ingressantes na Universidade de Estudos Internacionais de Shanghai (curso criado em 1977), 55 formados e 97 ingressantes na Universidade de Comunicações da China (curso estabelecido em 2000), 24 ingressantes em 2005 na Universidade de Estudos Internacionais de Pequim (curso criado em 2005).

No Brasil, nos anos 90, teve início um movimento convergente. À medida que a China se tornava cada vez mais inportante e influente no mercado mundial, os brasileiros começaram a aprender mandarim. Com o incremento dos negócios entre os dois países, muitos empresários e profissionais brasileiros perceberam que aprender mandarim era uma grande oportunidade de ganhar dinheiro. Sob esta necessidade, surgiram várias escolas e cursos de aprendizagem de língua chinesa. Em outubro de 2003, Yong Liang abriu em São Paulo o Centro de Línguas e Cultura Chinesa (Chinbra). Depois de um ano, mais de 150 alunos já haviam estudado a língua mais falada do mundo. Os alunos brasileiros levam pelo menos um ano para aprender o chinês básico. "Queremos ajudar a formar uma ponte cultural e comercial entre os dois gigantes, o asiático e o sul-americano", afirma o professor Alexandre Qi. 


\section{O curso de chinês na Universidade de São Paulo}

- Estabelecimento do curso e do corpo docente

O Curso de Língua Chinesa foi criado em 18 de setembro de 1962, construindo uma parte da Seção de Estudos Orientais do Departamento de História da FFLCH-USP. A implantação efetiva do curso ocorreu quando o diretor da Faculdade de Filosofia, Letras e Ciências Humanas, o Prof. Dr. Eurípides Simões de Paula convidou o professor de Belas Artes, Sun Chia Chin, cujo mestre era Zhang Da Qian, o mais famoso pintor chinês do século passado, para implementar o Curso de Chinês. Em 1970, depois de terminar o ensino de um curso de pósgraduação na República da China, o Prof. Sun Chia Chin foi finalmente contratado para ministrar o curso de chinês.

Em 1970, devido à reforma universitária, o Curso de Chinês passou para a área de Letras, integrando o Departamento de Lingüística e Língua. Posteriormente, com a subdivisão deste, o curso passou a integrar o Departamento de Línguas Orientais da FFLCH - USP.

Na história do Curso de Chinês, foram contratado vários professores como em 1971, o Prof. Nicolau Chen Mu Yu, que se dedicou muito à formação do corpo docente brasileiro; em 1972, a Prof $^{\mathrm{a}}$ Therezinha Miguel Naked Zaratin, a primeira docente brasileira e formada pelo próprio Curso de Chinês; em 1975, o Prof. Alexander Chung Yuan Yang; em 1978, a Prof ${ }^{a}$ Maria da Graça de Campos Mendes, também formada pelo Curso de Chinês, em 1988, o atual Coordenador do Curso de Chinês, o Prof. Mário Bruno Sproviero foi contratado após haver colaborado durante treze anos, como professor voluntário.

Com esforço de especialistas chineses e brasileiros e vários professores voluntários, criou-se um curso de graduação de Chinês. Com o aumento da importância econômica e política da China no âmbito internacional, tornou-se necessá- 
ria a formação de sinólogos, pesquisadores e quadros diplomáticos fazendo com que o curso de Chinês se tornasse cada vez mais procurado.

Em 2002, no Curso de Língua e Literatura Chinesa tinha 4 docentes para a graduação sendo 2 deles titulados para levar adiante a implantação da área de pós-graduação.

Atualmente, os docentes são Mário Bruno Sproviero, David Jye Yuan Shyu, Chen Tsung Jye, Ho Ye Chia e Sylvio R. G. Horta.

\section{- Intercâmbio com Universidades Chinesas}

A partir de 1985, quando foi assinado o Acordo de Cooperação Cultural e Educacional entre o governo da República Federativa do Brasil e o governo da República Popular da China, o intercâmbio com instituições universitárias e governamentais chinesas aumentou significativamente. Até hoje, o Curso de Língua e Literatura Chinesa mantém programa de professores visitantes de universidades chinesas pelo convênio estabelecido com instituições públicas e privadas.

Foram os seguintes professores visitantes: o Prof. Li Chun Pao, da Universidade de Línguas Estrangeiras de Beijing, de 1987 a 1989; a Prof ${ }^{a}$ Meng Aiqun, da Universidade de Línguas Estrangeiras de Beijing, de 1994 a 1996; o Prof. Jia Fu Tian, da Universidade de Fu-Dan, de 1997 a 1999, e em 2002, o Prof. Pan Zhong Qiu, da Universidade de Línguas Estrangeiras de Shanghai. Atualmente, o curso conta com a colaboração da Profa. Wu Liu, da Universidade de Estudo Estrangeiro de Guangzhou. Os professores visitantes vêm ministrando aulas na Graduação, proferindo palestras e auxiliando na confecção de material didático para o Curso de Chinês. 
- Os alunos formados

De 1992 a 2004, foram formados 16 alunos do curso de graduação. A turma de 2005 tem 11 alunos, o que significa um aumento de graduandos em 2006.

\section{- Cursos e pesquisa}

O departamento oferece disciplinas optativas para graduandos, os quais são: Língua Chinesa I e II, Língua Chinesa Clássica I e II, Cultura Chinesa I e II, Literatura Clássica Chinesa I e II, Literatura Contemporânea Chinesa I e II.

Além do nível de graduação, existem também cursos de extenção e difusão cultural.. Eles são Introdução Panorâmica e Cultural da Língua Chinesa, Pintura e Caligrafia Chinesa, Aspectos Culturais da Língua Chinesa.

A pesquisa promovida pela área de Chinês da FFLCH-USP concentra-se em três campos: língua, literatura e cultura. No campo da língua, visa-se a aprendizagem da língua chinesa, tanto falada quanto escrita. No campo da literatura, concentra-se na literatura clássica, no período Primavera e Outono e Estudos Combatentes (772 a.C. - 256 a.C.), a poesia na Dinastia Tang (618 d.C. - 960 d.C.), assim como a Literatura Contemporânea. No campo da cultura, pesquisamse a origem da cultura chinesa, a formação do Império Chinês (221 a.C.), a adaptação da China à Cultura Ocidental e sua influência sobre o mundo de hoje.

Os docentes do curso têm realizado estudos e trabalhos científicos como dissertações de mestrado, teses de doutorado e artigos, traduções, comunicações em eventos culturais, palestras e conferências dentro das linhas de pesquisa como estudos lingüísticos, literários e culturais da língua chinesa, bem como multiculturalismo brasileiro, fisionomia e presença chinesa. 
O corpo docente tem participado de várias reuniões e associações científicas nacionais e internacionais tais como: Associação Latino-Americana de Estudos Afro-Asiáticos (ALADAA); Associação dos Professores de Língua Chinesa do Brasil (São Paulo, Brasil); Associação Nacional de Professores Universitários de História (ANPUH); Associação dos Professores de Lingüística (São Paulo, Brasil); Sociedade Brasileira para o Progresso da Ciência (SBPC).

Digna de nota também, são os diversos congressos e seminários realizados, entre os quais destacam-se: Congresso Nacional de Docentes e Pesquisadores Chineses e Sinólogos do Brasil de 8 a 11 de setembro de 1995; Seminário "Projeção da China no Brasil - Dialogo Cultural”, maio de 1999; Seminário de Professores de Língua Chinesa no Brasil, setembro de 1999; Congresso Internacional "Trinta anos de vivência e cultura dos imigrantes chineses na América do Sul, outubro de 1999; Seminário de Recursos Informáticos para Ensino de Língua Chinesa, maio de 2000; Seminário de Professores da Língua Chinesa no Brasil, julho de 2002.

Em 1994, o Curso de Língua, Literatura e Cultura Chinesa lançou a revista China em Estudo que continua até hoje. A edição mais recente é a $6^{a}$ e foi lançado em 2004.

\subsection{Literatura}

Nos últimos 30 anos, foram traduzidas várias obras pelos dois países. Dae literatura em língua portuguesa, foram traduzidas para o chinês as principais obras de Machado de Assis, José Saramago, Fernando Pessoa, José de Alencar, Luís de Camões, Eça de Queiróz, Sérgio Buarque de Holanda, Paulo Coelho etc. Por outro lado, a maioria da obras de literatura chinesa traduzidas em português são poesias das dinastias antigas e obras fundamentadas no Confucianismo e no 
Taoismo. Entre elas, incluem ainda as obras de chinês traduzidas para o português a partir de versões do inglês, o que gera inevitavelmente lacunas e deslocamentos de significado por causa do efeito de refração da terceira língua. A tradução de mais obras centrais da literatura chinesa será tarefa para os especialistas das duas línguas no futuro.

\subsubsection{Relações Comerciais - 30 anos da parceria estratégica}

Em novembro de 2004, o presidente da China, Hu Jintao visitou o Brasil para consolidar a nova parceria estratégica entre os dois países. Em seu discurso perante o Congresso brasileiro, o presidente da China foi categórico: "Há 30 anos, a China e o Brasil, os dois maiores países em desenvolvimento, respectivamente, dos hemisférios leste e oeste, juntaram as mãos como um evento histórico ao estabelecer relações diplomáticas. Trinta anos transcorridos, passamos hoje a desenvolver plenamente a parceria estratégica, cujos elementos estão se enriquecendo crescentemente".

No período de 24 a 27 de maio de 2004, 460 empresários, de 315 empresas brasileiras, acompanharam a visita da comitiva presidencial do Brasil à China, e contribuíram para a realização bem sucedida da maior missão empresarial organizada pelo governo brasileiro em um país estrangeiro, segundo o Ministério das Relações Exteriores (MRE). A avaliação positiva desses empresários expressa nas respostas ao questionário do Departamento de Promoção Comercial do Ministério das Relações Exteriores (DPC/MRE), e publicadas no respectivo relatório, confirma a importância de eventos como estes para intensificar a cooperação com empresas daquele país: $72 \%$ declararam ter efetuado ou encaminhado negócios com parceiros chineses, sendo $57,7 \%$ de parceria, $34,6 \%$ de exportação e $7,7 \%$ de importação.

\footnotetext{
${ }^{2}$ Revista Visão da China. Edição Especial de 2004. São Paulo, Câmara de Comércio e Indústria Brasil-China. 2004. P. 18-22.
} 
Inicialmente tratada como retribuição à visita do presidente Luiz Inácio Lula da Silva, os encontros realizados durante a visita do presidente $\mathrm{Hu}$ Jintao ao Brasil consolidaram as relações bilateriais. Acompanhado por uma comitiva de $150 \mathrm{em}-$ presários chineses interessados em investir no Brasil, o Presidente visitou Brasília, Rio de Janeiro e São Paulo entre os dias 12 e 16 de novembro de 2004.

Hoje , a China é o terceiro parceiro comercial do Brasil, perdendo apenas para os Estados Unidos da América e Argentina, sendo que as relações comerciais sino-brasileiras vêm crescendo cada vez mais e ainda há potencial para muito mais. O volume de comércio bilateral entre dois países chegou a US $\$ 14,8$ bilhões no ano de 2005, e, segundo algumas estimativas, este valor pode dobrar até 2007. O diretor de Importação e Exportação do Ministério do Comércio da China, Li Minglin, projeta que em 2010, o comércio entre os dois países atinja a cifra a US\$ 35 bilhões, o que representará uma grande fatia do comércio brasileiro.

Nesse sentido, os dados quantitativos que se seguem números revelam um pouco mais do potencial para que os dois países venham a tornar-se grandes parceiros comerciais. Com efeito, de janeiro a agosto de 2005, o Brasil exportou para a China um total de US $\$ 4,1$ bilhões, valor $6,1 \%$ superior ao registrado valor de US\$3,8 bilhões em igual período de 2004, e importou US\$3,3 bilhões, o que significa um incremento de $43,37 \%$ em relação a 2004 . O volume total de comércio no ano 2005 entre dois países chegou a US\$14,8 bilhões, $20 \%$ superior ao de 2004. Segundo o relatório estatístico de comércio exterior do Brasil, no primeiro quarto de 2006, o comércio bilateral entre dois países atingiu US\$ 3,17 bilhões, US\$ 1 bilhão superior ao registrado valor em igual período de 2005 , equivalente a um aumento da ordem de $46,5 \%$, e representando um novo recorde.

Esta intensificação nas relações entre Brasil e China resultará em uma mudança do mapa comercial do mundo. "Estamos redesenhando o mapa mundial em termos de fluxo de mercadorias e rotas comerciais", afirmou o presidente do Brasil. Já o ministro do Comércio da China, Bo Xilai, lembrou o grande mercado for- 
mado por 1,3 bilhão de chineses, com necessidades que a indústria e a produção brasileiras podem suprir em vários setores. Para ele, o Brasil, além de deter vários tipos de riqueza que faltam à China, tem muitos outros atrativos, que vão do futebol à soja.

Os investimentos e as compras de soja, minério e aviões da China estão cada dia mais importante para o Brasil. Por outro lado, a China precisa cada vez mais dos produtos estratégicos para poder alimentar seu povo, e sustentar as demandas da indústria. Na esfera internacional, Brasil e China têm atuado em sintonia nas organizações e fóruns políticos econômicos, como na OMC (Organização Mundial de Comércio) e nas Nações Unidas. O presidente da China assinalou que a China continuará apoiando a cooperação benéfica mutuamente entre as duas nações em todos os setores. "Com nossos esforços conjuntos, as relações de associação estratégica de amanhã entre a China e o Brasil serão mais fortes", disse. 3

Várias empresas brasileiras instalaram fábricas na China, em associação com empresas e/ou governos locais. Muitas outras têm comprado lá parte dos produtos que vendem, a exemplo dos casos notíciados há pouco, da Gradiente, que trouxe em 2004 um total de $\mathrm{R} \$ 175$ milhões em aparelhos eletrônicos chineses prontos, vendidos com a marca da empresa; a Gulliver, com metade do faturamento obtido com brinquedos que ela mesma importou da China; e a Hering, com jaquetas devidamente etiquetadas com os dois peixinhos, feitas pelos chineses.

\section{Perspectivas para o futuro}

Os principais acordos assinados entre os dois governos abrangem as mais diversas áreas, tais como a cooperação nas áreas de turismo, ciência e tecnologia (inclusive indústria aeroespacial), agricultura, comércio e investimento.

\footnotetext{
${ }^{3}$ Revista Visão da China. Edição Especial de 2004. São Paulo, Câmara de Comércio e Indústria Brasil-China. 2004. P. 18-22.
} 


\section{China abre mercado para carne e frango brasileiros}

Os Presidentes Luiz Inácio Lula da Silva e Hu Jintao assinaram quatro protocolos sobre condições sanitárias para a exportação de carne bovina, suína e de aves, por parte do Brasil. O Potencial de exportação da carne de ave para a China aumentou devido à doença conhecida como "gripe do frango", da qual Brasil é declarado oficialmente livre. Segundo o ministro da Agricultura do Brasil, Roberto Rodrigues, o acordo para a exportação de carne bovina para a China deve gerar US\$ 600 milhões por ano para o país.

Enquanto a exportação de carnes se expande, o governo brasileiro já pensa em ampliar a venda de frutas e derivados de soja para a China. Um grupo de estudo de trabalho foi criado para avaliar as questões realacionadas à exportação da soja, derivados, frutas e verduras.

\section{Turismo: destino aprovado}

A visita do Presidente Hu Jintao em novembro de 2004 rendeu também um acordo para facilitar a vinda de turistas chineses ao Brasil.

Atualmente, 15 mil chineses visitam anualmente o Brasil, e entre 13 e 17 mil brasileiros visitam a China. o principal motivo da vinda ao Brasil são as viagens de negócios e eventos, mas, segundo estudos realizados pelo ministério do Turismo brasileiro, os chineses gostam de visitar lugares exóticos e com natureza exuberante. No Brasil, os locais mais visitados são o Rio de Janeiro, Foz do Iguaçu e a região amazônica. O turismo de praia não é muito apreciado. As relações culturais servem para aproximar ainda mais os dois países e aprofundar o intercâmbio em todos os aspectos, como nas áreas econômica e cultural, disse o diretor-geral do Gabinete de Informação do Conselho de Estado da República Popular da China, Yang Yang. "Para os chineses o Brasil é uma terra fascinante". 
Para o ministro do turismo, Walfrido dos Mares Guia, o acordo abre definitivamente as portas da China para os brasileiros e as portas do Brasil para os chineses. "Vamos ter estratégias de marketing, a promoção do Brasil, abrir um escritório de turismo do Brasil em Xangai, combinar pacotes com as linhas aéreas e trabalhar de mãos dadas com as operadoras chinesas", afirmou.

Os pontos centrais do acordo de turismo são:

1. Troca de listas de operadores entre Brasil e China, indicando as operadoras cadastradas de alta qualidade na China e o no Brasil.

2. Cada uma das operadoras deverá oferecer uma linha de 0800 para emergências com tradução.

3. Os grupos deverão ter à disposição guias que falem chinês e inglês.

4. Os turistas chineses não mais necessitarão ir à embaixada brasileira para conseguir os vistos. Poderão enviar um procurador levando todos os passaportes do grupo e receber os vistos sem a necessidade de apresentar passagens ou comprovante de renda.

Segundo a estimação da Organização Mundial do Turismo, a China seja o quarto maior emissor de turistas do mundo até 2020, cada ano enviando 100 miIhões de visitantes, e o primeiro país em destino turístico do planeta. Com o ADS (Status de Destino Aprovado), concedido pelo governo chinês ao Brasil no final do ano 2004, o Ministério do Turismo estima que o país passe a receber 100 mil chineses por ano até 2007, segundo a assessoria de comunicação da Embratur. O ADS já foi concedido pela China à União Européia e a 34 outros países, e permite que empresas de turismo montem e vendeam pacotes a chineses para visitar estes países. O Brasil é o segundo país das Américas a conseguir o acordo, depois de Cuba.

Além disso, a companhia aérea brasileira Varig coopera com Air China no estabelecimento de um vôo direto para fortalecer a ligação aérea entre os dois paí- 
ses. Segundo reportagem da Aviação Brasil no dia 13 de março de 2006, este vôo já começou desde 12 de março. Serão vôos diários, via Frankfurt, com saídas do Rio de Janeiro e de São Paulo.

O presidente Luís Inácio Lula da Silva assinalou que a intensificação dos contatos entre nossas sociedades será um passo essencial na ampliação do conhecimento mútuo e no aprofundamento de nossas relações.

\subsection{Dicionários atuais de português e chinês}

No momento atual, os únicos dicionários bilíngües chinês/português são o $D i$ cionário conciso português-chinês ${ }^{4}$ e o Dicionário conciso chinês português ${ }^{5}$.

\subsubsection{Dicionário conciso de português-chinês}

Sua primeira edição data de agosto de 1994, com uma primeira reimpressão em maio de 1995. Foi o primeiro dicionário de português publicado na China. Contém 50.000 verbetes, entre incluindo vocábulos, termos, afixos, derivados, etc. Os autores tinham consultado vários dicionários de Portugal, do Brasil e de outros países da língua portuguesa.

1) Macroestrutura:

a) Prefácio e instruções

b) Lista de abreviaturas, siglas e sinais (Anexo 1)

c) Alfabeto de português

d) Texto principal

e) Anexo1 - Formas de conjugações

Anexo2 - Tabela de junção de preposição com artigos, pronomes, etc.

Anexo3 - Tabela de países e suas capitais

Anexo4 - Tabela de unidades de pesos e medidas

Anexo5 - Lista de elementos químicos (Anexo 2)

2) Microestrutura: verbete (Anexo 3)

a) Informação gramatical da palavra

b) Definições (sigla de área em frente); exemplos; preposição para verbo.

\footnotetext{
${ }^{4}$ ZHOU, H.J.;WANG, Z.Y.;ZHAO, H.L.;CUI, W.X. Dicionário Conciso Português-Chinês. Beijing, R.P.China. Comercial Press. 1995.

${ }^{5}$ WANG, S. ; LU, Y. Dicionário Conciso Chinês-Português. Shanghai, R.P. China. Shanghai Foreign Language Education Press. 1997.
} 
c) Locuções e expressões

\subsubsection{Dicionário conciso de chinês - português}

O dicionário foi publicado em agosto de 1997 e saiu a $2^{\mathrm{a}}$ impressão de 2000 exemplares em outubro de 1998. É o primeiro e único dicionário de chinês e português da China. Os dois autores deste dicionário eram professores de português na Universidade de Estudos Internacionais de Shanghai e mudaram a viver em Portugal. Consequentemente, este dicionário trata principalmente o português europeu (PE).

1) Macroestrutura:

a) Instruções

b) Índice remissivo por radicais e números de traços de ideograma (Anexo 4 e 5)

c) Índice remissivo pela ordem alfabética de Pinyin (alfabeto fonético de sílabas latinas com tons, somente para pronunciar, sem significado) (Anexo 6)

d) Texto Principal

e) Anexo1 - Tabela de conversão de chinês tradicional (linguagem escrita do mandarim em Taiwan) para chinês simplificado (da China continental).

2) Microestrutura: Verbete (Anexo 7)

a) Termo em chinês simplificado

b) Versão de chinês tradicional

c) Pinyin (notação fonética)

d) Definições gerais

e) Termos especializados e locuções 


\section{FUNDAMENTOS TEÓRICOS}

\subsection{Aspetos históricos e conceptuais da terminologia}

\subsubsection{Definições básicas}

\subsubsection{Terminologia}

Desde tempos remotos, os homens criam e utilizam palavras para expressar e denominar conceitos, objetos e processos das diferentes áreas do conhecimento especializado. Essa produtividade lingüística, que é geral e inerente ao uso da linguagem e das línguas, ocorre de forma mais evidente nos campos das ciências, das técnicas e demais atividades de trabalho profissional. Assim, com o incremento das ciências e das técnicas, de forma continuada e especialmente acelerada a partir da revolução industrial, torna-se cada vez mais evidente a preocupação com a conceituação e com a denominação "corretas", de modo a assegurar a inteligibildade mútua nos diversos intercâmbios do saber e do saber-fazer humanos. Das nomenclaturas da biologia e da química e da constituição do sistema métrico universal, derivará, naturalmente, uma linha de reflexões e pesquisas que, no século XX, desemboca na Terminologia e na Terminografia.

O dicionário "Aurélio" (edição de 1986) traz a seguinte definição:

"terminologia. [Do lat. terminu, 'termo' + '-log(o)-' + -ia] S. f. 1. Conjuntfo de termos [v.termos (s)] próprios de uma arte ou de uma ciência; nomenclatura. 2. Tratado acerca desses termos. 3. Emprego de palavras peculiares a um escritor, a uma região, etc. 4. Estudo da idendificação e delimitação de conceitos peculiares a qualquer ciência, profissão, arte, ofício, etc. e da designação de cada um deles por um certo termo (Ferreira, 1986, p.1667). “

\subsubsection{Correlações e interfaces}

Além de Terminologia, três outras disciplinas têm na "palavra" o seu objeto de estudo, que são Terminografia, Lexicologia e Lexicografia. Embora todas trabalhem com a mesma "matéria-prima", cada uma a organiza diferentemente, tanto nos modelos teóricos e métodos de análise específicos, quanto nas delimitações e 
definições.

\subsection{Lexicologia}

A Terminologia toma como objeto de investigação o termo. Seu objetivo é investigar o componente lexical especializado ou temático. Um outro ramo da Lingüística, a Lexicologia, também baseia-se neste componente. Lexicologia e Terminologia, embora se aproximem, distinguem-se pela especialidade de seus objetos. Diferentemente da terminologia, que investiga a palavra em seu uso em uma linguagem de especialidade, a Lexicologia ocupa-se da palavra no contexto da língua geral.

$\mathrm{Na}$ análise lexical, levam-se em consideração todas as possibilidades de realização e de significação em uma dada língua. Assim, por exemplo, a unidade lexical cobre é estudada pela lexicologia em todos os seus significados em conformidade com o nível de línguagem (popular, familiar), de acordo com as áreas especializadas (em química, na metalurgia), e com outros aspectos. Já a Terminologia, leva-se em consideração apenas o significado que a unidade terminológica cobre possui na área específica (em metalurgia, por exemplo) na qual está sendo analisado.

Nesse caso, a diferença entre os dois estudos é que, a Lexicologia estuda o componente lexical da língua geral e a Terminologia estuda o componente lexical das linguagens especializadas.

\subsection{Lexicografia}

A Lexicografia é definida como a arte ou a técnica de compor dicionários. "A lexicografia conservou, desde suas origens, o sistema de estabelecer a relação entre os elementos de um léxico as equivalências elaboradas na mesma língua, que vieram substituir as traduções, destinadas a revelar os significados..." 6

\footnotetext{
${ }^{6}$ REY, A. Le lexique: images et modèles. Du dictionnaire à la lexicologie. Paris, Librairie/Armand Colin, 1977. P. 15.
} 
Estas obras dicionarísticas compostas pela Lexicografia, são obras monolíngües, bilíngües e multilíngües, registram a unidade lexical geral de um idioma, reunindo seu conjunto de palavras e locuções. Hoje em dia, existem grandes dicionários que incluem também terminologia em seus repertórios, para que estas completem o componente lexical das línguas.

Os dicionários gerais apresentam informações etimológicas, fonológicas, gramaticais, bem como a indicação de usos específicos (regionais ou socioletais) entre outros aspectos.

A Lexicologia contribui muito para a Lexicografia, orientando o dicionarista na realização de intensa pesquisa para constituir a nomenclatura geral da obra, a estrutura dos verbetes, bem como as definições.

Considere-se o quadro comparativo abaixo, proposto por Krieger. 


\section{Quadro $1^{7}$}

\section{Comparativo entre Lexicologia e Terminologia}

\begin{tabular}{|c|c|c|}
\hline & Lexicologia & Terminologia \\
\hline Vertentes & Prática e teórica & Prática e teórica \\
\hline Origem & Tradição & Contemporaneidade \\
\hline Objeto & Léxico geral/palavra & Léxico temático/termos \\
\hline Produto & $\begin{array}{l}\text { Dicionários de língua mono, bi e } \\
\text { multilíngües }\end{array}$ & $\begin{array}{l}\text { Léxicos, glossários, dicionários termi- } \\
\text { nológicos mono, bi e multilíngües, } \\
\text { bancos de dados terminológicos }\end{array}$ \\
\hline Natureza & Lingüístico-descritiva & Cognitiva-normalizadora \\
\hline $\begin{array}{l}\text { Objetivos e } \\
\text { funções }\end{array}$ & $\begin{array}{l}\text { 1. Repertoriar o léxico geral } \\
\text { 2. Oferecer informações etimo- } \\
\text { lógicas, gramaticais, sociolin- } \\
\text { güísticas } \\
\text { 3. Oferecer informações semân- } \\
\text { ticas gerais e especializadas } \\
\text { de todas as unidades lexicais } \\
\text { de um idioma (polissemia) } \\
\text { 4. Oferecer padrões de usos } \\
\text { lingüísticos } \\
\text { 5. Legitimar o léxico de uma lín- } \\
\text { gua }\end{array}$ & $\begin{array}{l}\text { 1. Repertoriar o léxico temático } \\
\text { 2. Oferecer informações terminoló- } \\
\text { gicas e conceituais de uma área } \\
\text { de conhecimento especializado } \\
\text { 3. Delimitar conceitos de um siste- } \\
\text { ma cognitivo específico (homoní- } \\
\text { mia) } \\
\text { 4. Estabelecer padrões de designa- } \\
\text { ção e conceituação em áreas de } \\
\text { especialidade (normatização) }\end{array}$ \\
\hline Usuário & Difuso & Específico \\
\hline Fontes & Textos em geral & Textos de especialidade \\
\hline Método & Semasiológico & Onomasiológico \\
\hline \multicolumn{3}{|c|}{ Entradas } \\
\hline $\begin{array}{l}\text { Critério de } \\
\text { seleção }\end{array}$ & Freqüência & $\begin{array}{l}\text { Pertinência do termo à área de co- } \\
\text { nhecimento/freqüência em menor es- } \\
\text { cala }\end{array}$ \\
\hline Tipologia & $\begin{array}{l}\text { Verbal: palavras gramaticais e } \\
\text { lexicais }\end{array}$ & $\begin{array}{l}\text { Verbal: termos simples, compostos, } \\
\text { siglas e acrônimos } \\
\text { Não verbal: símbolos e fórmulas }\end{array}$ \\
\hline Tratamento & Lematização, forma canônica & $\begin{array}{l}\text { Manutenção da forma plena e recor- } \\
\text { rente }\end{array}$ \\
\hline
\end{tabular}

\footnotetext{
${ }^{7}$ KRIEGER, M. da G. \& FINATTO, M. J. B. Introdução à terminologia - teoria \& prática. São Paulo, Contexto, 2004. P.54.
} 


\subsection{Terminografia}

Entende-se por terminografia um estudo aplicado à produção de glossários, dicionários técnicos ou terminológicos e bancos de dados. É também chamada de Lexicografia Especializada. Esse campo de atividade não se confunde com a Lexicografia, embora embas aproximem-se em propósitos gerais, porquanto possuem objetos específicos e metodologias ao menos parcialmente diferentes.

A Terminografia pode ser definida como:

"Trabalho e técnica que consiste em recensear e em estudar termos de um domínio especializado do saber, em uma ou mais línguas determinadas, considerados em suas formas, significações e relações conceituais (onomasiológicas), assim como em suas relações com o meio socioprofissional." 8

\section{$\underline{\text { Tipos de obras }}$}

As metodologias terminográficas orientam a estabelecer obras terminológicas tais como glossários, dicionários terminológicos mono, bi ou multilingües ou ainda bancos de dados de terminologia.

Esses três tipos de obras, embora apresentem finalidades semelhantes, possuem caraterísticas particulares. O Glossário costuma ser definido como repertório de unidades lexicais de uma especialidade com suas respectivas definições ou outras especificações sobre seus sentidos. É composto sem pretensão de exaustividade. O dicionário terminológico ou técnico-científico é uma obra que registra o conjunto de termos de um domínio oferecendo primordialmente informações conceituais e, por vezes, lingüísticas. Carateriza-se por uma cobertura exautiva de itens lexicais. Já o banco de dados terminológicos é uma estrutura informatizada que contém uma lista de termos e um repertório de termos, além de uma série de

\footnotetext{
${ }^{8}$ BOULANGER, J. C. Convergências e divergências entre a lexicologia e a terminologia. Porto Alegre: UFRGS, 2001. P. 13.
} 
outras informações relativas ao uso e funcionamento das terminologias. ${ }^{9}$

Segundo Krieger e Finatto (2004), as diferenças entre Terminografia e Lexicografia são seguintes:

1) Em Terminografia, cada termo constitui a entrada do verbete das obras de referência especializada, e é registrado numa forma modificada tais como no feminino, no plural, conforme utilizada nas comunicações profissionais. No caso do léxico geral, as entradas são sempre registradas no masculino singular, para os nomes e no infinitivo, para os verbos;

2) Em Terminografia, termos como sintagmas podem ser entrada de verbete, na Lexicologia, sintagmas e as locuções são partes de verbete;

3) Terminografia oferece consultante informações de uma área específica. Por outro lado, a Lexicologia busca cobrir todos aspectos de uma palavra;

4) Um dicionário geral baseado na teoria de Lexicografia oferece informações sobre a Língua. "Por exemplo, um dicionário geral diria que: sabão é '[Do latim, Sapone], Substantivo masculino. Substância detergente usada com água para lavagem de roupas, superfícies, utensífios, etc.'(adaptado de Ferreira, 1986 e Houaiss e Villar, 2001). De outro lado, uma definição química de sabão seria formalada como 'substância de função química salorgânica que tem a propriedade de detegência por apresentar na sua estrutura uma região polar e outro apolar."” 10

Em um quadro-síntese proposto por Barros (2004, p. 64) encontamos

\footnotetext{
${ }^{9}$ KRIEGER, M. da G. \& FINATTO, M. J. B. Introdução à terminologia - teoria \& prática. São Paulo, Contexto, 2004. P.51.

${ }^{10}$ KRIEGER, M. da G. \& FINATTO, M. J. B. Introdução à terminologia - teoria \& prática. São Paulo, Contexto, 2004. P.52 e 53.
} 


\section{Quadro $2^{11}$}

As semelhanças e diferenças entre Lexicologia, Lexicografia, Terminologia e Terminografia

\begin{tabular}{|l|l|l|l|l|}
\hline & Lexicologia & Lexicografia & Terminologia & Terminografia \\
\hline $\begin{array}{l}\text { Campo de } \\
\text { atuação }\end{array}$ & Língua geral & Língua geral & $\begin{array}{l}\text { Língua de es- } \\
\text { pecialidade }\end{array}$ & $\begin{array}{l}\text { Línguas de es- } \\
\text { pecialidade }\end{array}$ \\
\hline $\begin{array}{l}\text { Unidade } \\
\text { padrão de }\end{array}$ & $\begin{array}{l}\text { Unidade lexical, } \\
\text { lexema }\end{array}$ & $\begin{array}{l}\text { Unidade lexical, } \\
\text { lexema }\end{array}$ & $\begin{array}{l}\text { Unidade termi- } \\
\text { nológica, termo }\end{array}$ & $\begin{array}{l}\text { Unidade termi- } \\
\text { nológica, termo }\end{array}$ \\
\hline $\begin{array}{l}\text { Nível de } \\
\text { atualização } \\
\text { da unidade } \\
\text { lexical }\end{array}$ & Sistema & Sistema & $\begin{array}{l}\text { Norma(s) de } \\
\text { especialidade }\end{array}$ & $\begin{array}{l}\text { Norma(s) de } \\
\text { especialidae }\end{array}$ \\
\hline $\begin{array}{l}\text { Tipo de } \\
\text { disciplina } \\
\text { científica }\end{array}$ & Básica & Básica/aplicada & Básica & Básica/aplicada \\
\hline $\begin{array}{l}\text { Tipos de } \\
\text { obras }\end{array}$ & $\begin{array}{l}\text { Dicionários de } \\
\text { línguas, dicio- } \\
\text { nários especi- } \\
\text { ais, thesaurus } \\
\text { linguae e outros }\end{array}$ & & $\begin{array}{l}\text { Vocabulários } \\
\text { técnicos, cientí- } \\
\text { ficos, especiali- } \\
\text { zados }\end{array}$ \\
\hline
\end{tabular}

\subsubsection{História de terminologia}

\subsubsection{Nascimento e desenvolvimento}

O nascimento da Terminologia remonta aos tempos mais antigos. O Homem dá nome aos animais, às plantas, aos instrumentos e a tudo o mais que o cerca. Sempre que no interior de uma especialidade (um ramo específico do saber e do saber-fazer humanos) se percebe a necessidade de comunicar-se com outro grupo humano que fala uma língua diferente, passa a organizar o acervo do seu léxico e a empreender a busca de equivalentes. Assim, nascem os dicionários bilíngües, que registram os termos ou as palavras de uma área específica como agricultura, medicina, comércio etc.

Segundo pesquisa atestada, desde 2600 a.C., surgem dicionários temáticos

${ }^{11}$ BARROS, L. A. Curso Básico de Terminologia. São Paulo, EDUSP, 2004. P.64. 
monolíngües em forma de tijolos de argila, destinados ao registro de termos "relacionados a profissões, gado, objetos comuns e divindades; registravam-se os termos aceitos pelas escolas de escribas e constituíam o fundamento do dicionário mais completo compilado por volta de 2200 a.C." 12

No fim do Médio Império faraônico (c. 1800 a.C), surgiram no Egito os primeiros dicionários temáticos e no começo da era cristã, Herodianus e Heródoto elaboraram glossários que explicavam os termos médicos utilizados pelo grego Hipócrates (c. 460-377 a.C).

Nas eras seguidas, surgem mais dicionários monolíngües e multilíngües especializados em diversas área, sobretudo em medicina.

Quando os tradutores antigos traduziam uma obra estrangeira, encontram termos especializados que não existem no idioma próprio, então criam termos novos, que são os neônimos.

Em 1370, quando Nicolas d'Oresme traduzia a Política, a Economia e a Ética de Aristóteles, notou que não existiam termos em língua francesa para expressar conceitos de filósofo grego, criou então, neônimos como aristocracia, déspota, demagogo, legislação e outros. ${ }^{13}$

No século XVII, começam a se formar os elementos básicos da terminologia como conjunto de termos especializadas de uma área. Em 1864, o termo terminologia adquiriu um espaço nos dicionários europeus, que descreviam-o como palavra que designa um conjunto de termos técnicos de uma área específica. Como campo de estudo a terminologia é finalmente registrada na terceira edição do Webster. No entanto, é somente a partir dos anos 60 que os termos derivados

\footnotetext{
${ }^{12}$ VAN HOOF, H. Os Tradutores e os Dicionários. Os Tradutores na História. São Paulo, Ática, 1998. P. 245.

${ }^{13}$ VAN HOOF, H. Os Tradutores e os Dicionários. Os Tradutores na História. São Paulo, Ática, 1998. P. 245.
} 
de terminologia tornam-se mais freqüentes a partir dos anos 1960.

Nos anos de 1930, o engenheiro austríaco Eugen Wüster (1898-1977) estabeleceu a Escola Terminológica de Viena e elaborou mais tarde sua Teoria Geral da Terminologia (TGT), consagrando a Terminologia como disciplina científica que estuda os termos de uma área específica.

Na China, o estudo da terminologia só ganha corpo até 1950, porém, nos últimos anos do império e na $1^{\text {a }}$ República da China, ou seja, nos primeiros 20 anos do século $X X$, já surgiram dicionários técnicos na área de ciência natural e humana, os quais são Vocabulário de Física e Química em 1908, Dicionário de Engenharia de chinês e português em 1915, entre outros dicionários técnico-científicos nas áreas como medicina, matemática, zoologia e botânica.

A partir dos anos de 1970, as teorias e metodologias terminológicas terminográficas passam por grandes transformações e se desdobram em várias abordagens e alternativas. Ao mesmo tempo, organizam-se diversos eventos acadêmicos e cursos de Terminologia no mundo todo.

"A partir de 1996, o InfoTerm tornou-se uma associação internacional independente. Em 1977, nasceu a Rede Internacional de Terminologia (TermNet), impulsionada pelo InfoTerm." 14

Segundo Lidia Almeira Barros, os estudos terminológicos internacionalizam-se rapidamente e chegam à França, ao Canadá, à Bélgica e à Dinamarca. Em seguida, despertam interesse na América Latina, no Mediterrâneo, na Península Ibérica e na África. Mais recentemente, chegam à China e ao Japão.

A produção de obras terminográficas torna-se cada vez maior por conta de desenvolvimento de tecnologia, e chegam aos atuais bancos de dados on line e 
CD-ROM mais sofisticados.

\subsubsection{Evolução histórica}

Segundo Cabré (Cabré, 1993, p.28), a evolução histórica de Terminologia é dividida em quatro períodos, os quais são: de 1930 a 1960 (origens), de 1960 a 1975 (estruturação), de 1975 a 1985 (eclosão), e a partir de 1985 (expansão).

$$
\underline{1930-1960}
$$

A Terminologia como disciplina científica surge na Alemanha, com Wüster, e na ex-URSS, com Lotte. Aparecem os primeiros trabalhos que procuram delinear a estrutura teórica e a metodologia da Terminologia. Predomina neste período uma abordagem vinculada à epistemologia das ciências, resultando em posturas sobretudo normativas.

\section{$\underline{1960-1975}$}

Com o progressivo desenvolvimento da informática, especialmente da microinformática, surgem os primeiros bancos de dados terminológicos mono, bi e multilíngües. As dimensões da Terminologia alargam-se internacionalmente e multiplicam-se os esforços de normalização das línguas de especialidade e das terminologias.

\section{$1975-1985$}

Este período é marcado pela proliferação de metodologias e abordagens que transportam a Terminologia, ainda que parcialmente, para o domínio da Lingüística. e pela popularização da informática.

\footnotetext{
${ }^{14}$ BARROS, L. A. Curso Básico de Terminologia. São Paulo, EDUSP, 2004. P.64.
} 
A partir de 1985 e toda a década de 1990

No final dos anos de 1980 e os anos de 1990, os estudos terminológicos passam por notável incremento. Passa a configurar-se de forma definitiva como uma disciplina da Lingüística. E difunde-se por todos os continetes: a patir de . países da Europa, da ex-URSS, e do Canadá, chega à América Latina, Portugal, Espanha e aos países africanos e asiáticos. Surgem obras terminológicas em diversas áreas especializadas, novas teorias e associações internacionais que coordenam o intercâmbio e a cooperação científica. A microinformática começa a difundir-se após 1985, o que facilita os pesquisadores a estudar e processar os dados terminológicos.

\section{Década de 1990 aos dias atuais}

As teorias e metodologias foram aplicadas e aprovadas. Surgem novos questões e propostas na Socioterminologia, na Teoria Geral de Terminologia (TGT) e na Teoria Comunicativa de Terminologia (TCT) sugeridas por Maria Teresa Cabré (....). No Brasil, as referências relevantes são Alves (....), Aubert (....), Barbosa (.....), Faustlich (...) e Krieger (...).

\subsubsection{A Terminologia no Brasil}

A Terminologia começa no Brasil nos anos de 1980, como uma disciplina em cursos superiores de Letras e/ou de Tradução. No início, foi desenvolvida nas Universidades em que os pesquisadores já efetuavam estudos e ministravam de Lexicologia e Lexicografia, principalmente na Universidade de São Paulo (USP), na Universidade Federal de Brasília (UnB) e na Universidade Federal do Rio Grande do Sul (UFRGS). Nesses institutos, formaram-se muitos dos mestres e doutores que contribuem para a implantamentação de Terminologia no Brasil. Hoje em dia, muito mais universidades brasileiras exploram nesse campo. 
Embora esse estudo seja desenvolvido principalmente na pós-graduação, a Terminologia já começa a ser disciplina, básica ou eletiva, na graduação, especialmente nos cursos de Tradução e Interpretação.

Em 1986, foi estabelecida o Grupo de Trabalho Lexicologia e Lexicografia na Associação Nacional de Pós-Graduação em Letras e Lingüística (Anpoll). Depois de dois anos, esse grupo passou a ser denominado como Lexicologia, Lexicografia e Terminologia.

Em 1990, organizou-se o II Simpósio Ibero-americano de Terminologia e o I Encontro Brasileiro de Terminologia Técnica e Científica. Foi criada a Comissão de Estudo Especial Temporária de Terminologia (CEETT), que é composta por especialistas das áreas de Terminologia. Mais tarde, foi elaborado o projeto "BrasilTerm" - Banco de Dados Terminológicos do Brasil, que contém todos termos científicos e técnicos do português do Brasil.

O BrasilTerm tem como objeto "difundir e estimular o uso da terminologia técnico-científica no território nacioal, bem como subsidiar a implementação do Banco de Dados Terminológicos do Mercosul".

Nos últimos anos, a pesquisa terminológica no Brasil vem dando passos significativos, e surgem inúmeras obras terminológicos. O ensino e a pesquisa terminológica já ocupam um espaço importante no Mundo.

\subsubsection{A terminologia na China}

\subsection{Obras terminológicas de chinês na China antiga}

Os estudos terminológicos em base científica na China só ensaiam os seus primeiros passos na primeira década do século $X X$; conhece-se, entretanto, na história da China antiga, a elaboração de várias obras de termos da medicina e de outras ciências naturais e humanas. 
Há 2000 anos, o primeiro dicionário chinês Er Ya recolheu vários termos relacionados às acepções iniciais da ciência natural e humana; na Dinastia Tang $(618-907)$, Yi Qie Jing Yin Yi (fonética e significado de sutra) explicou os termos de Budismo; durante período de Dinastia Song Norte (960 1127), o livro Ying Zao Fa Shi (métodos de construção) estipulou os termos da arquitetura; Na Dinastia Ming (1368 - 1644), o famoso farmacéutico Li Shizhen nomeou muitos animais, plantas e minas na sua obra na área de medicina Ben Cao Gang Mu (Compendio de Matéria Médica); Xu Guangqi criou vários termos na área de agronomia e irrigação no seu livro Nong Zheng Quan Shu (Enciclopédia de administração agrícola); Song Yingxing recoIheu vários termos de construção no livro Tian Gong Kai Wu ; Ge Zhi Jing Yuan da Dinastia Qing (1644 - 1911); e Ci Hai (Oceano de Palavras) iniciado na Dinastia Qing e terminado somente em 1936, em que estão elaboradas várias nomenclaturas e termos científicos e princípios de definições.

Desde a Dinastia Yuan (1271 - 1368), o estudo do Ocidente facilita a penetração na China de tecnologias científicas contemporâneas ocidentais . Em 1582, o missionário italiano Matteo Ricci (1552 - 1610) partiu de Goa na Índia e chegou a Macau, onde iniciou posteriormente a introdução de ciências ocidentais na China. Nos séculos seguintes, os cientistas chineses traduziram várias obras científicas ocidentais como (Elementos, Euclides, 300 a.C.), (Manual de Mineralogia, J.D. Dana, 1813 1895), (Elementos de geologia, C. Lyell, 1865), (Princípios e Aplicações da Química, D.A. Wells, 1858), entre outras. Na área de língua estrangeira, na Dinastia Ming (1368 - 1644), foi publicado Hua Yi Ci Dian (Dicionário de chinês e língua estrangeira), que contém termos básicos do Sânscrito, Árabe, etc.

Em 1904, Du Yaquan traduziu e publicou pela Commercial Press vários mate- 
riais didáticos, tais como

Zhi Wu Xue Kuang Wu Xue (Botânica e Mineralogia) e Zui Xin Kuang Wu Xue (Mineralogia Atualizada), nas quais introduziu e criou vários neologismos e termos. Em 1908, a mesma editora publicou Wu Li Xue Ci Hui (Vocabulário de Física) e Hua Xue Ci Hui (Vocabulário de Química), que vêm a constituir os primeiros dicionários técnico-científicos publicados na China. Em 1915, a mesma editora publicou Hua Ying Gong Cheng Zi Hui (Dicionário de Engenharia de Chinês e Inglês), que é um dos primeiros dicionários de especialidade bilíngües elaborados por especialistas chineses. A elaboração deste dicionário exigiu 20 anos de trabalho do famoso engenheiro ferroviário chinês, Zhan Tianyou. ${ }^{15}$

O primeiro instituto especializado em normalização de termos técnicocientíficos foi estabelecido em 1909, já no final da Dinastia Qing, como setor de organização de termos técnico-científicos no departamento de educação superior. Depois da Revolução Xin Hai, em 1912, o Instituto de Física e Química da Província de Jiangsu normalizou termos de física e química, enquanto que a Associação Médica Chinesa normalizou termos de medicina. Até 1915, já haviam sido normalizados termos das áreas de química, física, matemática, zoologia, botânica, medicina, etc. Em 1918, a Associação de Ciências da China redigiu o esboço do projeto de normalização de termos técnico-científicos. Em 1919, foi criado a Comissão de termos técnico-científicos e 1928 o Comitê de unificação de nomes traduzidos. Até 1931, foram normalizados termos de 14 áreas, constituíndo um primeiro momento de apogeu dos trabalhos terminológicos-terminográficos na China. Em 1932, foi fundado o Instituto Nacional de Tradução que dedicava-se particularmente a trabalhos envolvendo termos técnico-científicos. Daí até 1949, elaborou 60 projetos de terminologias técnico-científicos, constituindo o segundo ápice no trabalho de padronização dos termos técnico-científicos.

\subsection{Desenvolvimento da terminologia na República Popular da China}

\footnotetext{
${ }^{15}$ GONG, Y. Histórico de trabalho terminológico de chinês. Jornal de Instituto de Ciências Sociais da China.
} 
Em 1949, foi fundada a República Popular da China . Em maio de 1950, foi criado o Comitê de Normalização de Termos Acadêmicos, tendo o famoso escritor da época, Guo Moruo como coordenador. O Comitê foi dividido em 5 subcomissões: Ciências da Naturais, Ciências Sociais, Medicina e Saneamento, Literatura e Arte, e Situação Política. Estas sub-comissões, por sua vez, repartiam-se em diversos grupos de trabalho. $O$ Instituto de Ciências da China responsabiliza-se pela parte de Ciências Naturais, incluindo inclui Astronomia, Matemática, Física, Química, Zoologia, Botânica, Geologia, Geografia, Paleontologia, Arqueologia, Psicologia, Lingüística, Geofísica, Engenharia, Agronomia, etc. Àquela altura, havia 150 cientistas engajados no trabalho de normalização, incluindo cientistas famosos como Yan Jici, Hua Luogeng, Qian Sanqiang, Feng Depei, Mao Yisheng, Lv Shuxiang, entre outros.

Da década 50 a 60 do século XX, os especialistas esforçaram-se para examinar e publicar termos de dezenas de domínios, promovendo o desenvolvimento científico da China e o intercâmbio acadêmico da China com países estrangeiros.

Em meados da década 60 , o trabalho de normalização de termos técnicocientíficos foi interrompido pela Revolução Cultural.

Em março de 1978, realizou-se a Conferência de Ciências da China. Os cientistas e especialistas em terminologia solicitaram o reinício da instituição de normalização de termos técnico-científicos. O pedido foi aprovado em dezembro de 1978. No dia 25 de abril de 1985, estabeleceu-se o Comitê Nacional de Normalização de Termos da Ciência Natural. Os trabalhos de terminologia foram desenvolvidos conforme segue: "Primeiro, faz-se a matéria fundamental, a matéria unitária e a matéria da área principal; segundo, faz-se a matéria aplicada; a matéria integrada, e a matéria da sub-área". ${ }^{16}$

\footnotetext{
${ }^{16}$ Histórico de Comité Nacional de Termos Técnicos e Científicos. www.term.gov.cn/pages/his/index2.jsp Beijing, China.
} 
Dentro de dois anos, 27 sub-comissões foram estabelecidas. Em 12 de julho de 1987, conclui-se a elaboração dos termos de astronomia, publicados em setembro. Em 1996, o comitê passou a ser designado "Comitê Nacional de Termos Técnicos e Ciêntíficos". Nos anos seguintes, o Comitê publicou novos termos das áreas de Ciência da Informática, Astronomia, e normalizou nomes chineses de elementos químicos.

Com o apoio do Instituto de Ciências da China, do Ministério de Tecnologia Científica e do Departamento de Imprensa e Publicação, o Comitê Nacional de Termos Técnicos e Ciêntíficos lançou o periódico "Estudos de Termonologia Técnica e Ciêntífica" (www.term.org.cn) em 1998. Em 2002, constituiu-se o banco de dados terminológicos, aumentando a eficiência de trabalhos de normalização. Em 2003, o site do comitê de terminologia (www.term.gov.cn) foi estabelecido na internet, o que permitiu a busca gratuita de termos técnico-científicos publicados.

No âmbito internacional, o Comitê mantém intercâmbio e colaboração com instituições e especialistas terminológicos de vários países como Estados Unidos, Áustria, Canada, Japão, Alemanha, Rússia, Malásia, Espanha entre outros. Em julho de 2000, um grupo de terminólogos chineses visitou algumas instituições representativas da Europa, aprofundando a noção sobre a importância da normalização da terminologia e aprendendo experiências avançadas do mundo.

Além de normalização de termos do chinês da China continental, o comitê desenvolveu também trabalhos da normalização de termos técnico-científicos entre a China continental e Taiwan. Terminou o trabalho comparativo de 20 domínios tais como astronomia, ciência da informática, etc. Publicou ainda glossário comparativo de termos de sub-áreas relacionadas a aerologia, entomologia, navegação, farmácia e construção naval.

Nos 20 anos de trabalhos da Terminologia, o Comitê de Terminologia consti- 
tuiu 61 sub-comissões, e publicou termos técnico-científicos de 66 áreas. Cerca de 1800 especialistas estabeleceram 150 mil termos técnico-científicos. Com o desenvolvimento econômico da China, é de se prever que os estudos terminológicos avancem ainda mais para acompanhar o desenvolvimento da ciência.

As obras terminológicas publicadas em versão de papel e versão em CDROM são: Termos de Genética (segunda edição); Termos de Tecnologia Aeronáutica; Princípios de Nomeação de Química Macromolécula; Termos de Farmácia de Medicina Tradicional Chinesa; Termos de Construção Civil; Termos de Engenharia I, II, III; Termos de Dialéctica Natural; Termos de Produção Aquática; Termos de Sistema de Informação Geográfica; Termos de Eletricidade; Termos de Topografia; Termos de Biologia Chinês/Inglês/Chinês; Termos de Medicina I - VII; Termos de Tecnologia Computacional; Termos de Entomologia; Termos de Astronomia; Termos de Psicologia; Termos de Farmácia; Termos de Metalurgia; Termos de Pedologia/agrologia; Termos de Tecnologia de Irrigação; Termos de Engenharia Elétrica; Termos de Construção de Navio; Termos de Tecnologia de Ferrovia; Termos de Tráfego Rodoviário; Termos de Tecnologia de Navegação; Termos de Arquitectura, Jardinagem e Planejamento Urbano; Termos de Carvão; Termos de Física; Termos de Zoologia; Termos de Ciência Aerológica; Termos de Construção Química; Termos de Petróleo; Termos de Agronomia; Termos de Geologia; Termos de Embriologia; Termos de Matemática; Termos de Eletrônica; Termos de Mecânica; Termos de Biologia Celular; Termos de Anatomia Humana; Termos de Botânica; Termos de Automação; Termos de Paleontologia; Termos de Química Biológica e Física Biológica; Termos de Química; Termos de Ciência Oceânica; Termos de Fisiologia; Termos de Genética; Termos de Silvicultura; Termos de Microbiologia; Termos de Geofísica e Termos de Geografia.

\subsection{Teorias terminológicas}

\subsubsection{Principais teorias fundadoras}

Dentre as diversas matrizes teóricas que subjazem à pesquisa terminológica e à prática terminográfica, duas merecem especial destaque: a Teoria Geral da 
Terminologia (TGT) e a Teoria Comunicativa da Terminologia (TCT).

\subsubsection{Teoria geral da terminologia (TGT)}

O fundador desta teoria é Eugen Wüster (1898 - 1977), engenheiro austríaco, industrial e professor. Ele formou-se na Universidade Técnica de Berlim e especializou-se em engenharia eléctrica. Em 1930, defendeu sua tese de doutorado na Universidade de Stuttgart, intitulada Internationale Sprachnormung in der Tecknik, que estuda a normalização da linguagem técnica. Nos anos seguintes, publicou vários obras de princípios terminológicos, ministrou cursos da Terminologia nas universidades e trabalhou como presidente de inúmeros comitês de associações terminológicas nacionais e internacionais.

Segundo Wüster, a disciplina Terminologia tem como objetivo oferecer bases científicas para a eliminação da ambigüidade nos discursos técnicos e científicos. A Terminologia tem relações com a Lógica, a Teoria de Classificação, a Lingüística, e hoje em dia, com a Informática. Todavia, os termos utilizados em Terminologia são unidades independentes da gramática, do contexto e do discurso. O conteúdo do termo é separado da expressão específica do léxico, isto distingue a Terminologia das teorias lingüísticas de base saussuriana.

"Para Wüster, a Terminologia serve para identificar um conjunto de conceitos de uma área especializada, organizá-los em um sistema estruturado e defini-los sem necessidade de identificar com precisão." (Barros,2004, p.56) Serve também para identificar os significados próprios de termos que designam os conceitos. Essa concepção distingue a Teoria Geral da Terminologia da Lingüística Geral.

A Teoria Geral da Terminologia é diferente das teorias particulares da Terminologia. A primeira se define como uma disciplina científica que elabora os princípios e métodos gerais para construir base a todos tipos de trabalho terminológico. As teorias particulares elaboram leis e regras terminológicas para as áreas espe- 
cíficas.

A Terminologia pode ser dividida, conforme o objetivo do trabalho, em Terminologia descritiva e Terminologia normativa. A primeira coleta os dados terminológicos, define termos e elabora vocabulários. A segunda normaliza os conceitos de termos, e elimina ou reduzir as ambigüidades. O trabalho é executado por organizações nacionais e internacionais autorizados.

\subsubsection{Teoria comunicativa da terminologia (TCT)}

À medida que os estudos terminológicos foram sendo desenvolvidos nas últimas décadas, começaram a ficar patentes algumas limitações da TGT, o que conduziu à necessidade de uma nova proposta teórica e metodológica para a Terminologia.

Nessa pespectiva, uma das respostas foi proporcionada por Maria Teresa Cabré (vide Cabré, 19..., 20...), que concebeu a Teoria Comunicativa da Terminologia (TCT) . Cabré reconhece o valor dos princípios de Wüster e suas contribuições aos desenvolvimentos de estudos terminológicos, todavia, considera TGT reducionista e idealista, devido ao seu conceito de independência da Terminologia da Língüística Geral e do contexto.

Diferentemente da TGT, a TCT não aceita a distinção entre unidade terminológica (termo) e unidade lexical na língua geral. Considera que os termos são unidades lingüísticas que emprimem conceitos específicos e ao mesmo tempo, contêm a natureza de uma língua geral.

Além disso, a TCT não concorda que os termos são independentes de contexto lingüístico, cultural e social. "São unidades léxicas (como todo signo lingüístico), de um dado código e seu caráter de termo é ativado de acordo com seu uso 
em um contexto e situação adequados. " 17

$\mathrm{Na}$ TGT, considera-se um termo pertence a um dado domínio; para TCT, termos são usados tanto na língua geral quanto em um domínio. Segundo Cabré, a TCT seria, em suma:

"[...] uma macroteoria lingüística constituída por três teorias: uma teoria da gramática que inclua a variação dialetal e funcional; uma teoria da aquisição que explique em uma só proposta como se adquire o conhecimento e dê conta das correlações, identidades e diferenças entre as características e o processo de aquisição do conhecimento geral e o especializado em toda sua diversidade funcional; e uma terceira teoria da atuação que recubra em um só modelo o uso geral e o especializado em toda sua variada amplitude (temática, perspectiva, nível de especialização, propósito comunicativo, propósito funcional, tipo de texto, tipo de discurso etc.)" 18

Desse modo, a TCT torna-se uma nova teoria orientadora dos especialistas terminológicos, porque é mais adequada ao objeto de estudo da Terminologia e mais próxima da realidade.

\subsubsection{Objetos do estudo da terminologia}

\subsubsection{Termo}

O termo é uma unidade lexical com um conteúdo específico de uma área especializada. É chamado também de unidade terminológica. O conjunto de termos de uma área específica chama-se conjunto terminológico ou terminologia. ${ }^{19}$

Segundo a definição dos organismos internacionais de normalização, o termo é definido como a designação, por meio de uma unidade lingüística, de um conceito definido em uma língua de especialidade. ${ }^{20}$

\footnotetext{
${ }^{17}$ CABRÉ, M. T. "Una Nueva Teoría de la Terminología: de la Denominación a la Comunicación”. La Terminología: Representación y Comunicación. Barcelona, IULA, 1999a. P.123.

${ }^{18}$ CABRÉ, M. T. 1999a. P.120.

${ }^{19}$ BARROS, L. A. Curso Básico de Terminologia. São Paulo, EDUSP, 2004. P.39

20 ORGANISATION INTERNACIONALE DE NORMALISATION. Terminologie - vocabulaire. Genebra, ISO, 1990 (Norme Internacionale ISO 1087, 1990). P.5.
} 


\subsubsection{Fraseologia}

O domínio da fraseologia é compreendida como abarcando expressões idiomáticas, frases feitas e provérbios utilizados nas diferentes línguas, bem como locuções nominais e verbos, entre outros.

De acordo com o contexto comunicacional, a fraseologia divide-se em fraseologia da língua geral ou em fraseologias especializadas. Estas últimas são elementos constitutivos para a Terminologia. Essas estruturas coexistem ao lado dos termos, formando um complexo de expressão de conteúdos de áreas de especialidades. A metodologia para elaborar os produtos terminológicos com inclusão de termos e fraseologias é importante para usuários gerais e consideravelmente para tradutores ou especialistas terminológicos, quando a obra é bi ou multilíngüe.

\subsubsection{As Línguas de especialidade}

As línguas ou linguagens de especialidade constituem o campo de pesquisa para a Terminologia. As linguages de especialidade são entendidas como "sistema de comunicação oral ou escrita usado por uma comunidade de especialistas de uma área particular do conhecimento". ${ }^{21}$ São também chamadas de "tecnoletos", subsistemas da língua geral.

\subsubsection{Aplicações dos conhecimentos terminológicos}

\subsubsection{Traduções especializadas}

Para trabalhar com os textos técnicos, científicos e especializados, o tradutor precisa não só deter um bom domínio das línguas de partida e chegada, mas, também, dominar a terminologia da área de especialidade e as equivalências terminológias bilíngües da área de especialidade a que a tradução pertence.

Uma boa tradução não deve apenas expressar o conteúdo do texto de partida,

\footnotetext{
${ }^{21}$ PAVEL, S. \& NOLET, D. Manual de Terminologia [on line]. Disponível na www.translationbureau.gc.ca Arquivo capturado em 1 de setembro de 2002.P.124.
} 
mas fazê-lo da forma que melhor se aproxima com aquela que um falante nativo da língua de chegada o exprime.

Desde tempos remotos, os tradutores produzem glossários e dicionários. Hoje em dia, eles organizam bancos de dados via internet, sendo, a um só tempo, usuários e produtores de materiais terminográficos, deste modo apoiando o trabalho de outros especialistas em tradução e em outros áreas, e criadores de terminologias, mediante a cunhagem de termos novos nas diversas linguagens de especialidade.

\subsubsection{Ensino de línguas}

Durante a aprendizagem de uma língua estrangeira, o aluno começa por vocabulários mais básicos, e depois, aprofunda seu estudo em termos específicos de diversas áreas, tais como da alimentação, do vestuário, dos transportes etc.

O aluno ao estudar a linguagem geral, ele pode escolher os campos de maior interesse para obter um conhecimento mais útil e adequado a ele. Os dicionários monolíngües, bilíngües e multilíngües especializados ou gerais, são essenciais para essa aprendizagem.

\subsubsection{Ensino de disciplinas técnicas e científicas}

Segundo as discussões de professores de ensino técnico e científico, um dos obstáculos para aprendizagem dos alunos é o desconhecimento do vocabulário especializado, ou o mal emprego da terminologia específica, o que prejudiga a compreensão e a exposição de conceitos fundamentais das teorias.

Além disso, nos campos que sofrem mais influência de línguas estrangeiras, como informática pelo inglês, medicina pelo latim e pelo grego, e filosofia pelo latim, francês e alemão, é importante que os alunos que não são especialistas em línguas estrangeiras tenham um bom domínio dos termos estrangeiros ou neológicos. É por isso que os alunos de medicina e do direito estudam latim e os de in- 
formática estudam inglês.

Consequentemente, surgem materiais didáticos terminológicos com termos de cada área específica.

Além das aplicações citadas acima, os conhecimentos terminológicos são também úteis e aplicáveis nas ciências sociais e para fins de planejamento linguístico.

\subsection{Modalidade de trabalhos terminológicos}

\subsubsection{Tipologia de obras lexicológicas e terminológicas}

Entendemos obras lexicográficas como sendo dicionários de língua, dicionários especiais e consideramos obras terminográficas como sendo dicionários que contêm um conjunto de termos de um domínio especializado. Ressalve-se, porém, que todo tipo de obra lexicográfica ou terminográfica pode ser chamada de repertório ou dicionário.

Para compreender melhor essas obras, os terminólogos criaram várias propostas de classificação tipológica.

\subsubsection{Classificação por público-alvo e tipo de dado veiculado}

Incluem-se nesta categoria dicionários para crianças ou estudantes (Aurélio Escolar, Larousse Pour Débutants, etc). Nesta mesma categoria incluem-se dicionários que contêm informações lingüísticas e extralingüísticas, como um dicionário enciclopédico.

\subsubsection{Classificação por quantidade de unidade lexicais tratadas}

Segundo o número de registro de unidades léxicas, uma obra pode ser extensiva ou intensiva. Se o objeto da obra for elaborar o maior número possível de unidades de uma língua ou de uma área específica, será extensiva; se a obra ser- 
ve para oferecer grande número de informações (definições, etimologia, dados históricos, informação gramatical, etc), será intensiva.

\subsubsection{Classificação por ordem das entradas}

As obras podem ser estruturadas pela forma ou pelo conteúdo, ou seja, a organização das entradas será por em ordem alfabética ou por conteúdo.

\subsubsection{Classificação tipológica dos repertórios: Norma ISO 1087}

A Norma ISO 1087 (1990) classifica as obras terminográficas como segue:

6.2.1. dicionários: Repertório estruturado de unidades lexicais contendo informações lingüísticas sobre cada uma dessas unidades (ISO, 1990, p.10)

6.2.1.1 dicionário terminológico: (termo tolerado: dicionário técnico): Dicionário (6.2.1) que compreende dados terminológicos (6.1.5) relativos a uma ou várias áreas (2.2.)

6.2.1.1.1. vocabulário: Dicionário terminológico (6.2.1.1) baseado em um trabalho terminológico (8.2) que apresenta a terminologia (5.1) de um domínio (2.2) particular ou de domínio (2.2) associado. ${ }^{22}$

\subsubsection{Tipos de repertório segundo o Office de la Langue Française}

A tipologia proposta pelo organismo quebequense baseia-se fundamentalmente no nível de atualização de unidade lexical.

$$
\text { Quadro } 3^{23}
$$

Repertório proposto pelo Office de la Langua Française

\begin{tabular}{|c|l|}
\hline 1. dicionário & 1. vocabulário \\
\hline 1.1. dicionário de língua & 1.1 vocabulário alfabético \\
\hline 1.1.1. dicionário geral & \\
\hline
\end{tabular}

\footnotetext{
${ }^{22}$ ORGANISATION INTERNACIONALE DE NORMALISATION. Terminologie - vocabulaire. Genebra, ISO, 1990 (Norme Internacionale ISO 1087, 1990).

${ }^{23}$ BARROS, L. A. Curso Básico de Terminologia. São Paulo, EDUSP, 2004. P.141.
} 


\begin{tabular}{|l|l|}
\hline 1.1.2. tesauro & \\
\hline 1.1.3. dicionário especial & \\
\hline 1.2. dicionário enciclopédico & 1.2 vocabulário sistemático \\
\hline 1.3. dicionário ilustrado & 1.3. vocabulário monolíngüe \\
\hline 1.4. dicionário monolíngüe & 1.4 . vocabulário multilíngüe \\
\hline 1.5. dicionário multilíngüe & \\
\hline 1.6. dicionário de tradução & \\
\hline 1.7. dicionário terminológico & \\
\hline & 2. léxico \\
\hline & 2.1. léxico alfabético \\
\hline & 2.2. léxico sistemático \\
\hline
\end{tabular}

\subsubsection{Proposta de classificação tipológica de Lidia Almeida Barros}

Os critérios propostos por Barros são:

\subsection{Tipos básicos de repertório}

a. dicionário (de língua)

b. dicionário terminológico

c. glossário

d. enciclopédia

e. léxico

Os critérios para a classificação são: 1) nível de atualização da unidade lexical; 2) presença ou ausência de definições; 3) presença ou ausência de dados enciclopédicos

Quadro 4

Proposta de classificação tipológica

\begin{tabular}{|l|c|c|c|c|}
\hline & \multicolumn{2}{|c|}{$\begin{array}{c}\text { Nível de atualização da unidade } \\
\text { lexical }\end{array}$} & \multirow{2}{*}{ Definição } & $\begin{array}{c}\text { Dados enciclo- } \\
\text { pédicos }\end{array}$ \\
\hline & Sistema & Norma(s) & & - \\
\hline Dicionário & + & + & + & - \\
\hline Dicionário & - & + & + & - \\
\hline
\end{tabular}




\begin{tabular}{|l|c|c|c|c|}
\hline Terminológico & & & & \\
\hline Glossário & + & + & - & - \\
\hline Enciclopédia & + & + & - & + \\
\hline Léxico & - & + & + & - \\
\hline
\end{tabular}

1. Dicionário (dicionário de língua): registra uma grande quantidade de unidades lexicais ou fraseológicas de uma língua, bem como os diferentes sentidos da palavra. Apresenta obrigatoriamente definições mas não dados enciclopédicos.

2. Dicionário terminológico (vocabulário): registra unidades terminológicas de um ou de vários domínios. Apresenta obrigatoriamente definições mas nenhum dado enciclopédico.

3. Glossário (dicionário bilíngüe, dicionário multilíngüe): Não apresenta definições, dá somente uma lista de unidades lexicais ou terminológicas acompanhadas de seus equivalentes em outra língua.

4. Enciclopédia: Oferece dados de natureza extralingüística e referencial. Se apresenta também definições, é chamado de dicionário enciclopédico.

5. Léxico: Lista unidades lexicais, terminológicas ou qualquer tipo de expressão utilizada pelo autor que se considera de difícil compreensão do público leitor de uma obra. Desenpenha normalmente como apêndice da obra e apresenta as unidades lexicais e suas definições.

\subsection{Número de línguas}
a. monolíngüe
b. bilíngüe
c. multilíngüe

O glossário pode ser bilíngüe ou multilíngüe, mas nunca monolíngüe.

\subsection{Tipo de unidade lexical}

Os dicionários gerais contêm unidades lexicais em todos os seus sentidos e contextos, fornecendo informações de todos os aspetos. Os dicionários especiais 
tratam de um subconjunto desses componentes lingüísticos, como, por exemplo, provérbios, expressões idiomáticas, gírias, sinônimos, antônimos, ou especializase em informações gramaticais, como dicionário de verbos, adjetivos, etc.

\subsection{Ordem alfabética ou sistemática}

As obras lexicográficas usam principalmente a ordem alfabética na organização das entradas e as obras terminológicas usa tanto a ordem alfabética quanto a sistemática.

Além desses elementos citados, ainda há outros tipos de classificação. Em suma, para designar uma obra terminológica, usamos mais frequentemente os termos dicionário terminológico ou vocabulário, e menos o glossário. O termo glossário serve particularmente para designar uma lista de unidades lexicais ou terminológicas com seus equivalentes em uma ou mais línguas, sem definições, epode ser chamado de dicionário bilíngüe ou multilíngüe.

\subsubsection{Componentes estruturais dos repertórios}

\subsubsection{A macroestrutura}

A Macroestrutura de um repertório refere-se às informações gerais constantes de verbetes, anexos, índices, remissivos, ilustrações, partes temárticas, etc.

Os conteúdos da macroestrutura podem incluir uma introdução que contém informações básicas sobre a obra, tais como, público-alvo, objetivos, caraterísticas, uma listagem das abreviações e símbolos usados na obra, uma lista de entradas, bem como os verbetes propriamente ditos.

\section{Ordem alfabética contínua ou descontínua}

$\mathrm{Na}$ ordem alfabética contínua, a seqüência não é influenciada pelos espaços, nem pelas caraterísticas não alfabéticas, tais como, apóstrofos, hífens, cedilhas, tis, acentos diferenciais e outros. Quer dizer, ignora os elementos não alfabéticos 
e só organiza a ordem pelas letras alfabéticas nas unidades.

$\mathrm{Na}$ ordem alfabética descontínua, além da ordem principal antes dos elementos não alfabéticos, também se considera a seqüência de letras após hífens e apóstrofo. A ordem determinada pelos hífens, apóstrofos e outros elementos servem como subordem.

Um exemplo para comparação entre ordem alfabética contínua e descontínua:

\section{Quadro $5^{24}$}

\begin{tabular}{|l|l|}
\hline Ordem alfabética contínua & Ordem alfabética descontínua \\
\hline galinha & galinha \\
\hline galinha-arrepiada & galinha-arrepiada \\
\hline galinha-choca & galinha-choca \\
\hline galinha-d'água & galinha-d'água \\
\hline garinha-da-guiné & galinha-d'angola \\
\hline galinha-da-índia & galinha-da-guiné \\
\hline galinha-d'angola & galinha-da-índia \\
\hline galinha-da-numídia & galinha-da-numídia \\
\hline galinha-do-mato & galinha-do-mato \\
\hline
\end{tabular}

Segundo o exemplo acima, na ordem contínua o apóstrofo e o hífen são ignorados e somente a seqüência alfabética é considerada. Na descontínua, apóstrofo tem precedência em relação a letra.

\section{Ordem remissiva de um dicionário de ideograma}

Um dicionário de chinês tem dois tipos de sistema remissivo, um é da ordem alfabética organizado pela ordem de Pinyin (notação fonética de chinês)( Anexo 7.1-6), um outro é da ordem de radical e número de traços de ideogramas(Anexo 7.1-4 e 7.1-5). O texto de dicionário é organizado em ordem alfabética. Normalmente, um ideograma tem duas partes, uma parte de significado que é radical e

\footnotetext{
${ }^{24}$ BARROS, L. A. Curso Básico de Terminologia. São Paulo, EDUSP, 2004. P.153.
} 
uma outra parte fonética. O radical indica a informação etimologica e o significado do ideograma. Por exemplo, os ideogramas relacionados a água tem radicais como " ", " ", e " ", os quais parecem como fluxo de água. Os ideogramas relacionados a fogo tem radical de " ", que parece como chamas de fogo.

O sistema de radical e número de traços contém dois índices. O primeiro é lista de radicais na ordem de número de traços deles(Anexo 7.1-4), o segundo é uma lista de todas ideogramas devididas pelos diferentes radicais(Anexo 7.1-5). Dentro de uma lista de ideogramas do mesmo radical, os termos são listadas a ordem de número total de traços que construem a resta parte sem radical. Atrás de cada ideograma, tem número de página onde tem verbete deste ideograma com definição e outras informações.

Para achar a definição de um ideograma, o consultante vai primeiramente contar o número de radical deste ideograma e procurar no lista de radicais. O número atrás de cada radical vai guiar o consultante a página deste radical na lista de ideogramas. Desse modo, o consultante conta o número de traços do ideograma sem contar traços de radical e procura nos ideogramas do mesmo número de traços. Segue o número atrás do ideograma desejado e vai até a página da definição do ideograma.

Exemplo: ${ }^{25}$

- Índice de radicais

Radical de três traços

32 “ página 10

- Índice de ideogramas a ordem de radical e traços página 10 32 Radical “ ”

\footnotetext{
${ }^{25}$ WANG, S. ; LU, Y. Dicionário Conciso Chinês-Português. Shanghai, R.P. China. Shanghai Foreign Language Education Press. 1997.
} 
Dois traços (parte sem radical):

página 834

página 257

$\cdots$

$\underline{\text { Três traços }}$

página 226

página 291

- Texto de dicionário (microestrutura)

Página 226 fonética jiàn-jiāng

$\cdots$

jiāng

1. rio no centro do rio;

2. Rio Changjiang (Yangtsé) ;

jiāng hú: rios e lagos;

jiāng shān: 1) rios e montanhas - território do país

2) país; poder do Estado

\subsubsection{A microestrutura}

A microestrutura é a organização dos dados no verbete. Os dados veiculados pelo verbete diferenciam uma obra da outra. Um número mínimo de dados deve ser fornecido sobre a entrada.

O verbete mínimo é composto de um elemento lingüístico (a entrada), da informação gramatical e de uma definição. (Rey-Debove, 1971, p.155). Porém, os dados dos verbetes podem ser muito além do verbete mínimo.

\subsection{Paradigmas da microestrutura}

Barbosa (1999) propõe um modelo para elaboração de microestruturas. 
'Na segunda estrutura possível, o 'enunciado lexicográfico' constitui-se, então, de três macroparadigmas, três grandes zonas semântico-sintáxicas: paradigma informacional (PI), paradigma definicional (PD) e paradigma pragmático (PP). Esses macroparadigmas, por sua vez, podem subdividir-se em microparadigmas, variáveis em qualidade e em quantidade, conforme a natureza da obra lexicográfica, seus objectivos, limites e público-alvo."26

A partir da proposta acima, pode-se desenvolver uma microestrutura adaptada à elaboração das obras lexicográficas e terminográficas.

\subsection{A entrada}

1) A entrada é normalmente escrita em negrito e é separada do corpo do enunciado lexicográfico ou terminográfico;

2) Em um dicionário alfabético, o signo lingüístico em posição de entrada deve sempre começar por uma minúscula, diferentemente da escrita com maiúscula em enunciado comum; Já em um dicionário de chinês, não tem este exigência, pois o chinês não tem diferença de manúscula e minúscula.

3) No caso de um dicionário de línguas indo-européias, a entrada deve sempre ser colocada em forma original. No infinitivo, quando for um verbo, no masculino se for um substantivo ou um adjetivo, salvo nos casos em que o feminino comporte concepções distintivas importantes, e no singular, excepto os que forem plurais lexicais ou variações semânticas (a costa, a costas). Para um dicionário de chinês, não tem esta regra, porque na gramática de chinês, o verbo não tem conjugações e substantivos não tem singural e plural, nem género para adjectivos.

4) Os termos complexos devem manter sua ordem sintagmática como no momento da coleta dos termos. (Lidia Almeida Barros, 2004, p.158)

${ }^{26}$ BARBOSA, M. A. "Considerações sobre a Estrutura e Funções da Obra Lexicolográfica: Metodologia, Tecnologia e Condições de Produção". Colóquio de Lexicologia e Lexicografia. Lisboa, 


\subsubsection{A definição}

Definição é o enunciado no verbete que descreve o conteúdo de uma unidade lexical ou terminológica. Há três tipos fundamentais de definição, os quais diferenciam os tipos de obras lexicográficas, terminográficas e enciclopédica.

1) Definições lexicográficas: tratam mais de informações lingüísticas

2) Definições enciclopédicas: se ocupa principalmente de referentes e de descrição de "coisa"

3) Definições terminológicas: tratam predominantemente dos conhecimentos formais sobre "coisas" e fenômenos. ${ }^{27}$

O tipo de informação veiculada pela definição e o modelo de estruturação do enunciado definicional mostram a tipologia e finalidade da obra repertória. Não existe uma definição válida para dois dicionários.

Um dicionário de língua define a unidade lexical em todos seus sentidos dentro de um sistema lingüístico; já uma obra terminográfica define exclusivamente o conteúdo específico de termos em uma área especializada.

Requisitos para definição:

a) Não se deve utilizar cópulas do tipo "diz-se de", "significa", "é", "trata-se de", "indica" etc.;

b) Não deve conter em seu enunciado o termo definido;

c) Deve ser completa, sem, no entanto, veicular dados supérfluos e inúteis;

d) Deve manter com o termo definido uma relação de univocidade.

Exemplo: não se deve definir "automóvel" somente um veículo de transporte, uma vez que nem todo veículo de transporte é um automó- 
vel;

e) Deve se adaptar ao público-alvo, ou seja, a metalinguagem empregada deve estar de acordo com a capacidade de compreensão do leitor;

f) Quando houver possibilidade de se redigir a definição na forma afirmativa, não se deve utilizar a forma negativa;

g) palavras de sentido vago, ambíguo ou figurado não devem ser empregadas. $^{28}$

O critério mais importante a ser respeitado é a equivalência entre a seqüência definicional e a unidade lingüística definida, e, no caso de obras bilíngües, a equivalência entre termos da língua de partida e da língua de chegada. Num dicionário bilíngüe, se o termo terminológico expressa significado diferente na língua de chegada (LC), deve ser enunciado na parte de observações ou nas notas da obra.

\subsubsection{O sistema de remissivas}

\subsection{Funções e objetivos}

A função de remissivas é estabelecer a rede de conexões entre as unidades lexicais ou terminológicas, evitar o isolamento das mensagens, e ligar variantes.

\subsubsection{Tipos de remissivas}

O sistema de remissivas pode se apresentar na macroestrutura e/ou na microestrutura.

\subsection{Na macroestrutura}

Algumas entradas não contêm definições mas indicam um outro verbete onde o leitor encontra a definição completa.

Exemplo: esborcelar: V.t.d. V. esborcinar (Ferreira, 1986, p.681).

${ }^{28}$ BARROS, L. A. Curso Básico de Terminologia. São Paulo, EDUSP, 2004.P.165. 
esborcinar: V.t.d. 1. Partir as bordas de; cortar pela borda. 2. Golpear (1). [F. Paral.: desborcinar; sin. ger.; esborcelar] (idem, ibidem).

\subsection{Na microestrutura}

Na microestrutura, a remissiva é empregada por V. (ver), q.v. (queira ver), cf. (confronte, compare), asterisco, número de série, símbolo de classificação. Índice e outros.

1) Remissiva "Ver": Utiliza-se de modo geral a remissiva. Ver, Veja (V.) para dirigir o leitor a um verbete em que se encontram as informações que deseja.
a) Para indicar ao consulante uma forma mais adequada, preferível ou usual;
b) Variantes;
c) Da forma estrangeira para a vernácula;
d) Elementos de fraseologismos ou adjetivos, para indicar a expressão, locução ou lexia complexa à qual pertencem.

2) Remissiva "Queira Ver" e "Confronte":

a) A remissiva q.v. é geralmente empregada para aconselhar o leitor a consultar um outro verbete para completar as informações;

b) É utilizada também em situações em que a definição de uma unidade lexical, embora completa, pode não atender às necessidades dos consultantes;

c) Para orientar o leitor a consultar um verbete cuja entrada é uma variante ortográfica da unidade lexical procurada;

d) A remissiva cf. aconselha o consulante a buscar um outro verbete. Ela somente indicar a existência de unidades lexicais semelhantes.

3) Asterisco: o emprego do asterisco é para indicar ao consultante que aquela unidade marcada pelo asterisco é a entrada de um verbete e nele é definida. No dicionário de chinês não tem uso de asterisco.

4) Número de série e símbolo de classificação: indica o número do verbete 
onde estão todas as informações sobre o verbete procurado.

5) Índice

Um sistema de remissivas é somente necessário numa obra organizada pela ordem alfabética. Nos vocabulários sistemáticos, o sistema de remissiva é desnecessário, porque os termos são organizados pelas relações de sentido deles.

Por isso, encontra-se nos dicionários alfabéticos um índice alfabético e sistemático. Exemplo:

\section{$\mathbf{L}$}

langue de spécialité.

lemmatisation 5.5.3.3

liste d'exclusion 7.5

M

macrostructure 6.2 .3

microstructure 6.2 .2

mononymie

Neste vocabulário, os termos são organizados pela ordem alfabética, porém, atrás deles, segue-se número de classificação que obedece a uma seqüência (hierárquica) de sentido.

Por esta forma, a consulta a um verbete é conveniente e sem dificuldades de localizar um termo pelo sentido dentro desta obra. 


\section{METODOLOGIA DO TRABALHO TERMINOLÓGICO}

\subsection{Planejamento de projeto do glossário de comércio exterior}

\subsubsection{Objetivos e publico-alvo}

Sou falante nativa de chinês e aprendiz de língua portuguesa por 8 anos. Aconselhada por meu orientador, decidi fazer um trabalho útil para pesquisadores de ambas as partes. Visto que o comércio exterior é a área de intercâmbio mais intenso nas relações entre o Brasil e a China, optei então por elaborar um glossário de comércio exterior como minha dissertação de mestrado, pois acredito ser este um trabalho interessante e significativo para os falantes dessas duas línguas.

Além disso, como as relações sócio-econômicas entre China e Brasil estão tornando-se cada vez mais intensas devida à cooperação estratégica e à globalização mundial, uma comunicação eficiente entre os dois países é de extrema importância para as suas relações comerciais. Embora existam dicionários gerais de chinês-português e português-chinês, em área mais específica, como a de comércio exterior, ainda não existem dicionários especializados. Por este motivo, decidi dedicar meu estudo de mestrado ao projeto de um glossário de comércio exterior entre chinês e português, o que poderá facilitar a comunicação entre dois países na área comercial.

O público-alvo deste trabalho inclui, entre outros:

1) os diversos profissionais que atuam nas áreas de importação e exportação entre os dois países;

2) os tradutores e intérpretes da área de comércio exterior

3) os terminólogos da língua chinesa e da língua portuguesa;

4) os alunos de cursos de chinês (mandarim) no Brasil e de português na China.

\subsubsection{Delimitação de subárea}

O domínio de comércio exterior é extremamente variado. Inclui- subáreas como cotação, negociação, contrato, seguros, operações bancárias, pagamentos, 
transportes, direitos aduaneiros, alfandega, teoria de importação e exportação, políticas de comércio exterior, etc. Cobrir esta vasta gama de aspectos diversos em um único trabalho é tarefa para um trabalho de doutorado. Aqui, nos limites de uma dissertação de mestrado, o foco escolhido centra-se nos documentos utilizados como suporte às operações de comércio exterior e à terminologia relevante para a produção e a compreensão desses documentos.

Para a presente pesquisa, adotamos a seguinte árvore de domínio:

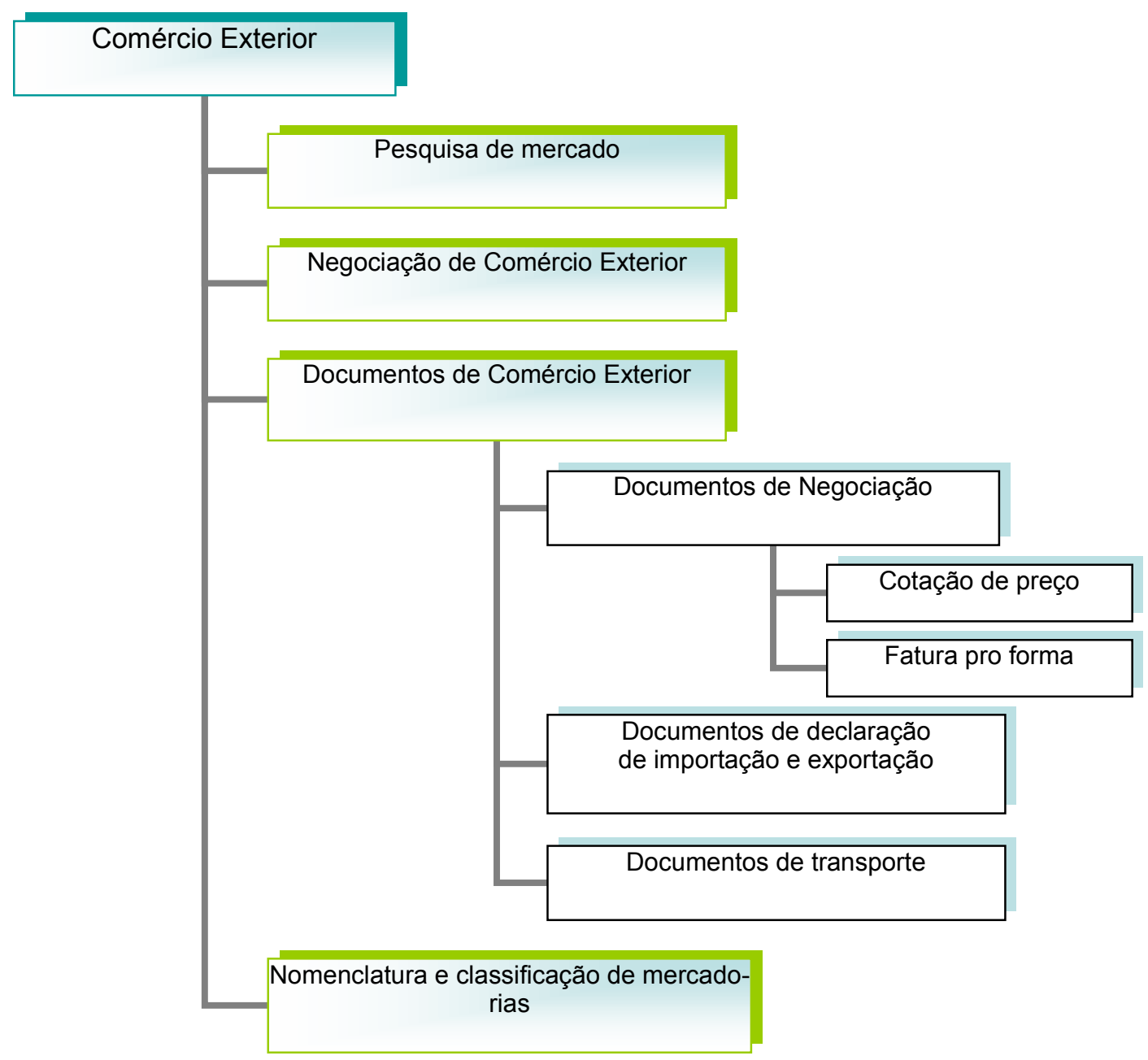




\subsubsection{Trabalhos de preparação}

$\mathrm{Na}$ elaboração de um projeto de glossário terminológico, incumbe ater-se, preliminarmente, aos seguintes pontos:

- Pesquisa bibliográfica e fontes do corpus de unidades terminológicas;

- A estrutura da obra, incluindo macroestrutura; microestrutura; anexos, etc;

- Planejamento e cronograma das diferentes etapas da execução de trabaIho: pesquisa bibliográfica, coleta e registro de ficha terminológica, tratamento dos dados, organização interna do glossário, consultas aos especialistas, etc;

\subsection{Execução do projeto do glossário de comércio exterior}

\subsubsection{Estabelecimento de corpus e coleta das unidades especializadas}

Em vista da opção feita pela terminologia pertinente aos documentos de comércio exterior, o corpus deste trabalho baseia-se nos documentos e formulários de importação e exportação. Recolhi as unidades especializadas do confronto destes documentos com livros, dicionários e outros documentos especializados em comérico exterior do Brasil e da China.

\section{Descrição e justificativa do corpus}

Na parte que se refere ao chinês, recorri a um dicionário monolíngüe em comércio e finanças e a um livro didático sobre documentos comerciais. Na parte que se refere ao português, recorri a dois dicionários monolíngües em comércio e um livro de teoria de comércio exterior do Brasil, nos quais contém também empréstimos de inglês. Na parte que se refere ao inglês, escolhi um dicionário de comércio exterior chinês/inglês.

Na parte relacionada com documentos de referência, recolhi os seguintes documentos: cotação de preço, fatura pro forma, fatura comercial, fatura aduaneira, fatura consular, romaneio, conhecimento de embarque aéreo, ferroviário, marítimo e rodoviário (que evidenciam o despacho da mercadoria), formulário de declaração de importação e exportação, nota promissória, certificado de origem, certifica- 
do de inspeção sanitária, licença de importação e exportação, carta de crédito, contrato de compra, saque, recibo de cais, carta de garantia bancária, lista de peso, ordem de compra e nota fiscal. Os documentos estão em chinês, português ou inglês.

O corpus do meu trabalho basea-se principalmente nos termos confirmados pelos dicionários terminológicos monolíngües. Na pesquisa, observo em cada língua os termos que expressam o significado semelhante ou igual. Se entre eles houver alguma equivalência, coloco um termo como entrada de verbete, e coloco o termo de outra língua como equivalência do termo da entrada.

O dicionário de inglês serve o propósito de proporcionar referência e contraponto aos consulentes e especialistas, pois a influência do inglês é inevitável na área de comércio exterior. Embora o glossário que aqui apresentamos contenha essencialmente termos equivalentes entre o chinês e o português, há casos que empréstimos do inglês são empregados de forma exclusiva, como por exemplo: FOB (Free on Board), CIF (Cost, Insurance and Freight), ou de forma alternativa bill of lading $(B / L)$ no lugar de conhecimento de embarque, etc. Nos casos em que o termo é único em chinês ou em português, e não se encontra uma equivalência de inglês, apresento uma proposta de tradução. Além de controlar as traduções propostas junto aos especialistas da área comercial, assinalo que a definição é traduzida por mim. A proposta neológica tem, à evidência, algumas limitações, podendo não vir a ser aceita pela prática dos usuários; entretanto, não deixa de representar uma solução, ainda que provisória, para termos sem equivalências na outra língua.

\subsubsection{Registro dos dados em fichas eletrônicas}

Encontrei vários tipos de fichários terminológicos na pesquisa bibliográfica. Finalmente estabeleci o fichário do meu trabalho de acordo com as sugestões dadas em Aubert (1996) e com as fichas propostas na disciplina de Lexicologia e Terminologia ministrada pela Profa. Dra. leda Maria Alves. 
A Ficha terminológica contem os seguintes dados:

1) Numeração

2) Número do documento de comércio exterior

3) Termo; (seguida pela notação fonética nos termos do chinês)

4) Informação gramatical;

5) Equivalentes em língua de chegada

6) Definição (Informação conceitual) em língua de chegada

7) Sinônimos em língua de chegada e/ou língua de partida

8) Equivalentes em terceira língua (inglês)

9) Observações

10) Fontes bibliográficas

11) Data de registro e modificação

A título de exemplificação, seguem 4 fichas terminológicos de documentos de comércio exterior. (CHN - chinês; PT - Português; ING - Inglês) 
Ficha 1 (CHN - PT)

\begin{tabular}{|c|c|c|c|}
\hline 1. & \multicolumn{3}{|c|}{ Númeração: 004} \\
\hline 2. & \multicolumn{3}{|c|}{ Documento de comércio exterior: Certificado de origem } \\
\hline 3. & \multicolumn{2}{|c|}{ Termo: } & Fonética: Chǎn Dì Zhèng Míng Shū \\
\hline 4. & \multicolumn{3}{|c|}{ Info. Gram.: s } \\
\hline 5. & \multicolumn{3}{|c|}{ Equivalência em PT: Certificado de Origem } \\
\hline 6. & \multicolumn{3}{|c|}{$\begin{array}{l}\text { Definição em PT: Documento que comprova o país de origem de } \\
\text { mercadorias transacionadas no mercado internacional. }\end{array}$} \\
\hline \multirow[t]{3}{*}{7.} & \multicolumn{3}{|c|}{ Sinônimo em CHN: } \\
\hline & a. & & (Yuán Chǎn Dì Zhèng Míng Shū) \\
\hline & b. & & (Chăn Dì Lái Yuán Zhèng) \\
\hline 8. & \multicolumn{3}{|c|}{ Termo ING: Certificate of origin } \\
\hline 9. & \multicolumn{3}{|c|}{ Observação: } \\
\hline \multirow[t]{3}{*}{10.} & \multicolumn{3}{|c|}{ Fonte bibliográfica: } \\
\hline & a. & \multicolumn{2}{|c|}{$\begin{array}{l}\text { WENG, F. X. Manual de Gráfico, Documentação e Certificados. } \\
\text { P.147. Hangzhou, Editora de Universidade de Zhejiang, } 2002 .\end{array}$} \\
\hline & b. & \multicolumn{2}{|c|}{$\begin{array}{l}\text { FILHO, E. G. Dicionário de Comércio Exterior e Câmbio. P.48. } \\
\text { São Paulo, Saraiva, } 2004 .\end{array}$} \\
\hline 11. & \multicolumn{3}{|c|}{ Data de registro: $26 / 04 / 2005$} \\
\hline
\end{tabular}


Ficha 2 (CHN - PT)

\begin{tabular}{|c|c|c|c|}
\hline 1. & \multicolumn{3}{|c|}{ Númeração: 005} \\
\hline 2. & \multicolumn{3}{|c|}{ Documento de comércio exterior: Licença de exportação } \\
\hline 3. & \multicolumn{2}{|c|}{ Termo: } & Fonética: Chū Kǒu Xǔ Kě Zhèng \\
\hline 4. & \multicolumn{3}{|c|}{ Info. Gram.: s } \\
\hline 5. & \multicolumn{3}{|c|}{ Equivalência em PT: Licença de Exportação } \\
\hline \multirow[t]{3}{*}{6.} & \multicolumn{3}{|c|}{ Definição em PT: } \\
\hline & a. & \multicolumn{2}{|c|}{$\begin{array}{l}\text { Um documento emitido por autoridades de um país, autori- } \\
\text { zando o direito a exportar uma quantidade especializada de } \\
\text { uma mercadoria para um país específico. }\end{array}$} \\
\hline & b. & \multicolumn{2}{|c|}{$\begin{array}{l}\text { Documento emitido pelas autoridades govenamentais de al- } \\
\text { guns países que permite a licença de determinados protudos } \\
\text { de exportação. }\end{array}$} \\
\hline 7. & \multicolumn{3}{|c|}{ Sinônimo em CHN: } \\
\hline 8. & \multicolumn{3}{|c|}{ Termo ING: Export license } \\
\hline 9. & \multicolumn{3}{|c|}{ Observação: } \\
\hline \multirow[t]{4}{*}{10.} & \multicolumn{3}{|c|}{ Fonte bibliográfica: } \\
\hline & a. & \multicolumn{2}{|c|}{$\begin{array}{l}\text { WENG, F. X. Manual de Gráfico, Documentação e Certifica- } \\
\text { dos. P.140. Hangzhou, Editora de Universidade de Zhejiang, } \\
2002 \text {. }\end{array}$} \\
\hline & b. & \multicolumn{2}{|c|}{$\begin{array}{l}\text { HINKELMAN, E. G. Handbook of the Global Trade Commu- } \\
\text { nity. } 4^{\text {th }} \text {.Ed. Versão Chinesa Traduzida por LI, J. P.169. Bei- } \\
\text { jing, Economic Science Press, } 2002 \text {. }\end{array}$} \\
\hline & c. & \multicolumn{2}{|c|}{$\begin{array}{l}\text { VAZQUEZ, J. L. Dicionário de Termos de Comércio Exterior. } \\
\text { P62. São Paulo, Atlas, } 2001 .\end{array}$} \\
\hline 11. & \multicolumn{3}{|c|}{ Data de registro: $15 / 05 / 2005$} \\
\hline
\end{tabular}


Ficha 3 (PT - CHN)

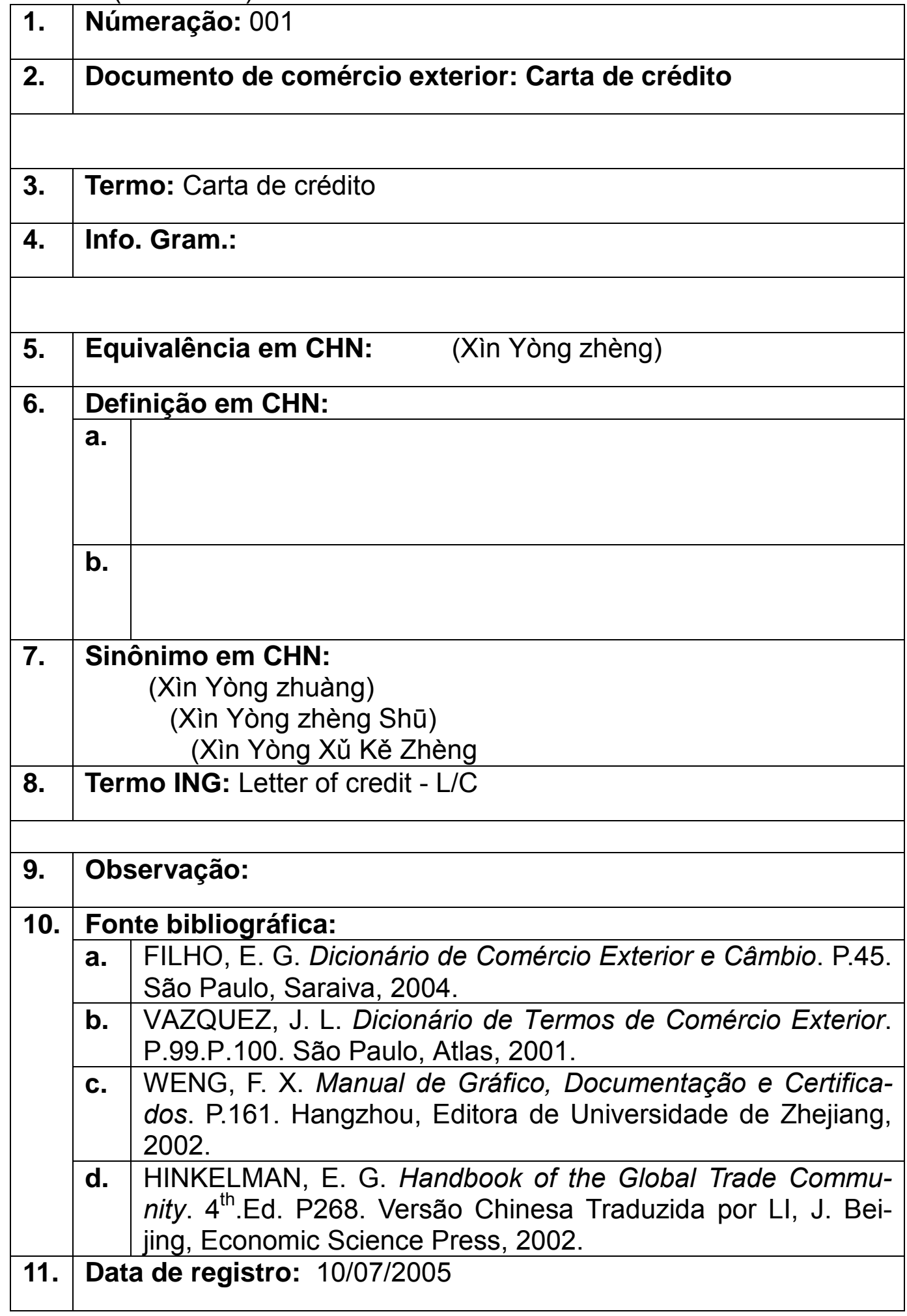


Ficha 4 (PT - CHN)

\begin{tabular}{|c|c|c|}
\hline 1. & \multicolumn{2}{|c|}{ Númeração: 003} \\
\hline 2. & \multicolumn{2}{|r|}{$\begin{array}{l}\text { Documento de comércio exterior: Certificado de inspeção sa- } \\
\text { nitária }\end{array}$} \\
\hline 3. & \multicolumn{2}{|r|}{ Termo: Certificado de Inspeção Sanitária } \\
\hline 4. & \multicolumn{2}{|c|}{ Info. Gram.: } \\
\hline 5. & \multicolumn{2}{|r|}{$\begin{array}{l}\text { Equivalência em CHN: } \\
\text { (Shāng Pìn Jiǎn Yàn Zhèng Shū) }\end{array}$} \\
\hline \multirow[t]{3}{*}{6.} & \multicolumn{2}{|r|}{ Definição em CHN: } \\
\hline & a. & \\
\hline & b. & \\
\hline 7. & \multicolumn{2}{|r|}{ Sinônimo em PT: Certificado Fitossanitário } \\
\hline 8. & \multicolumn{2}{|r|}{ Termo ING: Phytosanitary Inspection Certificate } \\
\hline 9. & \multicolumn{2}{|c|}{ Observação: } \\
\hline \multirow[t]{4}{*}{10.} & \multicolumn{2}{|c|}{ Fonte bibliográfica: } \\
\hline & a. & $\begin{array}{l}\text { VAZQUEZ, J. L. Dicionário de Termos de Comércio Exterior. } \\
\text { P124. São Paulo: Atlas, } 2001 .\end{array}$ \\
\hline & b. & $\begin{array}{l}\text { WENG, F. X. Manual de Gráfico, Documentação e Certifica- } \\
\text { dos. P.150. Hangzhou: Editora de Universidade de Zhejiang, } \\
2002 \text {. }\end{array}$ \\
\hline & C. & $\begin{array}{l}\text { HINKELMAN, E. G. Handbook of the Global Trade Commu- } \\
\text { nity. } 4^{\text {th }} . \text { Ed. P327. Versão Chinesa Traduzida por LI, J. Bei- } \\
\text { jing: Economic Science Press, } 2002 \text {. }\end{array}$ \\
\hline 11. & \multicolumn{2}{|r|}{ Data de registro: $12 / 07 / 2005$} \\
\hline
\end{tabular}




\subsection{Estrutura do glossário}

\subsubsection{Macroestrutura}

A macroestrutura do glossário compreende:

1) Apresentação

2) Abreviaturas

3) Parte chinês-português

a) Índice remissivo dos termos

b) Texto do glossário

4) Parte português-chinês

a) Índice remissivo dos termos

b) Texto do glossário

5) Anexos

6) Referência bibliográfica

\subsubsection{Microestrutura}

Segundo os modelos de verbete utilizados em diversas obras terminológicas, e tendo em vista o intuito de faelaborarzer um glossário com estrutura simples e clara, coloquei as sequintes informações no verbete:

1) Entrada de língua de partida (LP) em ordem alfabética;

2) Notação fonética do termo (se for entrada de chinês);

3) Informação gramatical;

4) Equivalência em língua de chegada (LC);

5) Equivalência na terceira língua (Inglês);

6) Definição em LC; Observações;

7) Número do anexo que contem o termo.

A microestrutura organiza-se como segue:

Exemplo 1: 
(Chū Kǒu Xǔ Kě Zhèng) [s]

PT: Licença de Exportação

ING: Export license

1) Um documento emitido por autoridades de um país, autorizando o direito a exportar uma quantidade especializada de uma mercadoria para um país específico. 2) Documento emitido pelas autoridades govenamentais de alguns países que permite a licença de determinados protudos de exportação.

Exemplo 2:

Certificado de Inspeção Sanitária [ ]

CHN: (Shāng Pìn Jiăn Yàn Zhèng Shū)

ING: Phytosanitary Inspection Certificate

1

\subsection{Problemática bilíngüe}

A produção de obras bilíngües é mais complexa do que a de obras monolíngües, pois cada língua contém em si aspectos culturais e modos de pensar que Ihes são próprios. Assim, o estabelecimento de equivalências pontuais e de uma suficiente precisão conceitual é problema chave na elaboração de uma obra bilíngüe.

\subsubsection{Equivalências e observacões}

"O problema dos glossários multilíngües em geral é, como já vimos, a equivalência lexical, uma vez que o recorte lingüístico-cultural pode não ser o mesmo em todas as línguas, o que cria lacunas ou impõe equivalências aproximativas. A falta de definições também pode provocar escolhas de equivalências estranhas ou mesmo errôneas." ${ }^{29}$

\footnotetext{
${ }^{29}$ BARROS, L. A. Curso Básico de Terminologia. São Paulo, Editora da Universidade de São
} 
Para garantir a precisão conceptual, escolhi os dicionários monolíngües especializados em comércio exterior de duas línguas. Com base nos significados ou nas definições propostas para cada termo nestes dicionários, procuro determinar se há equivalência completa entre eles, ou somente semelhança parcial. Nesta segunda hipótese, torna-se parte relevante do trabalho terminográfico inserir anotações explicando as diferenças .

\subsubsection{Solução para lacunas de equivalência}

Algumas línguas compartilham de uma mesma origem e possuem um universo lexical mais ou menos semelhante, adotando processos parecidos de criação neológica. Isto diminue as distâncias entre duas línguas e facilita a busca de equivalentes, tais como o caso de português e espanhol. Entretanto, português e chinês são dois sistemas lingüísticos radicalmente distintos; além disso, os países de cada língua possuem sistemas e regulamentos diferentes na área de comércio exterior. Consequentemente, ocorrem casos de ausência de equivalentes entre estas duas línguas (sob forma de intersecções apenas parciais ou mesmo de lacunas totais). Assim, por exemplo, o Brasil faz uso da Nota Fiscal, enquanto que na China só existe a Fatura Comercial, o que é traduzida em inglês como Commercial Invoice também. Neste caso, traduzi a definição de português de Nota Fiscal em chinês, e consultei a especialista de finanças quem conhecem tanto chinês quanto português para evitar erros.

Como tratar as unidades terminológicas que não encontram correspondência de realidade em outro idioma?

Uma das soluções freqüentemente adotadas em dicionários bilíngües é a explicação do fenômeno, objeto ou conceito da LP em LC. ${ }^{30}$

Uma outra possibilidade é a criação de um neologismo. Cabré distingue os

Paulo, 2004. P. 234

${ }^{30}$ BARROS, L. A. Curso Básico de Terminologia. São Paulo, EDUSP, 2004. P.247-249. 
neologismos, de acordo com sua função, em referenciais e expressivos: "Os primeiros aparecem porque são necessários, isto é, porque é preciso cobrir uma lacuna denominativa em um determinado campo de especialidade; o segundo tipo nasce simplesmente para introduzir novas formas expressivas na comunicação" ${ }^{\text {”1 }}$.

Recorrer a neologismos para a solução de problemas de lacunas de equivalência tem uma função somente referencial. A criação do termo pelo próprio terminólogo, sem comprovação prévia de sua utilização freqüente na realidade, pode revelar-se inócua. Segundo alerta Alpízar: "A criação de um neologismo para preencher uma lacuna no sistema é um procedimento de risco e só se deve decidir depois de muitas consultas a especialistas. Na maior parte dos casos não é recomendável. A função do dicionário não é criar palavras, mas registrar as existentes como o maior rigor científico possível”32. Por outro lado, o terminólogo não tem um papel que se confunde com o do dicionarista da língua geral e a propositura de neologismos - de preferência de construção sintagmática, auto-explicativos -, ainda que arriscada, pode revelar-se uma alternativa melhor para a manutenção da lacuna denominativa.

\subsection{Problemática da influência dos empréstimos do inglês}

\subsubsection{Influência do inglês no chinês e no português}

As origens dos neologismos estão ligadas a momentos históricos, a migração, a mudança sócio-econômicas, a todo tipo de ocasião que exige nomenclatura para situação ou objetos novos. A necessidade de denominar novos conceitos, novos objetos, novas invenções, novas situações, que venham a fazer parte de uma comunidade lingüística, dá origem aos neologismos. Além disso, a atividade humana registra no léxico novas maneiras de entretenimento, mudança de atitudes sociais, criação literárias. Poetas, jornalistas, romancistas, revisores, cientis-

\footnotetext{
${ }^{31}$ CABRÉ, M.T. La Terminología: Teoria, Metodologia, Aplicaciones. Barcelona, Editorial Antártida/Empúries, 1993. P.447.

${ }^{32}$ ALPIZAR Castillo, R. Como Hacer un Diccionario Científico Técnico? Buenos Aires, Memphis, 1997. P.103
} 
tas contribuem para esse tipo de enriquecimento vocabular.

Com a evolução da globalização mundial, e da facilidade de comunicação, a influência da língua e cultura inglesa fica cada vez mais visível. Não constitui exagero afirmar que o inglês já tornou-se uma língua universal em várias áreas contemporâneas de atividade, com destaque para as ciências em geral, a informática, a cultura, a economia, finanças, comércio, esportes, administração empresarial, etc.

Tanto o português quanto o chinês sofrem influências do inglês, gerando neologismos nas duas línguas, e nos conceitos mais novos, emprega-se diretamente os empréstimos ingleses. Para expressar idéias especializadas, o uso destes empréstimos são inevitáveis.

Tratamento de empréstimos estrangeiros no Chinês:

1) Tratamento de empréstimo pela notação fonética

Normalmente os empréstimos no chinês são nomes (substantivos) que não existiam na cultura chinesa e são adaptados pela criação de um neologismo com notação fonética semelhante à pronúncia de termo inglês, de tal modo como a tradução dos nomes e sobrenomes dos estrangeiros em chinês.

Exemplos:

a) Chocolate: empréstimo intermediado pelo inglês no chinês Pinyin: $\quad$ Qiăo Kē Lì (pronúncia semelhante à pronúncia inglesa)

b) Inglês: Jeep; Chinês: Jí Pǔ.

c) Inglês: Coffee; Chinês: Kā Fē̃.

d) Inglês: IT (Information Technology); Chinês: IT.

e) Português: Samba; Chinês: Sāng Bā.

2) Tratamento de empréstimo pelo significado

Para evitar a "invasão" de muitos empréstimos de línguas estrangeiras, os linguistas chineses também criam neologismos pelo significado e com o passar do tempo, estes termos neológicos integram-se ao chinês.

Exemplos:

a) Inglês: Computer; Chinês: Diàn Năo (Diàn - Elétrico; Năo - Cérebro) 
b) Inglês: Elevator; Chinês: Diàn Tī (Diàn - Elétrico; Tī - Escada)

c) Português: Carnaval; Chinês: Jiā Nián Huá; Kuáng Huān Jié (Kuáng: Loucura; Huān: Alegria; Jié: Festival)

3) Tratamento de empréstimo pelo significado e pronúncia Alguns neologismos tem uma pronúncia semelhante com a do termo orginal e ao mesmo tempo expressam um significado que não são expressos no termo orginal mas são razoáveis e correspondem às caraterísticas do objeto que descrevem.

\section{Exemplo:}

Inglês: Coca-cola; Chinês: Kě Kǒu Kě Lè (Kě Kǒu - gostoso; Kě Lè - agradável)

\subsubsection{Influência de inglês na área de comércio exterior}

Os neologismos e empréstimos de inglês são inúmeros na listagem de unidades terminológicas de comércio exterior. Como por exemplo: contêiner (container), backup, best-seller, bill of lading, cash flow, day trade, deadline, estoque (stock), FOB (Free on Board), holding, layout, OEM (Original Equipment Manufacturer), etc. ${ }^{33}$

\subsubsection{Aspectos potencialmente negativos e prejudiciais da influência} de inglês sobre comunicacão entre chinês e português

Por muitos anos, a comunição entre o mundo luso-brasileiro e o chinês deu-se através da interpretação do inglês, o que inevitavelmente levou ao surgimento de falsos cognatos e lacunas na compreensão mútua entre os povos das duas línguas. As unidades lexicais que somente existem na língua portuguesa foram traduzidas em língua inglesa pela equivalência parcial, mais tarde foram traduzidas pela segunda vez na língua chinesa. Diante da falta da equivalência completa em chinês, estas unidades acabaram sendo interpretadas de forma errada. Por exemplo: o termo 'Nota Fiscal' do português foi traduzido para o inglês como Commercial Invoice (Fatura comercial no português e no chinês), que em conseqüência foi traduzido para o chinês também como Commercial Invoice, no entan-

\footnotetext{
${ }^{33}$ TERRA, Ernani; DE NICOLA, José; MENÓN, Lorena Mariel. - 1001 Estrangeirismos de Uso Corrente em Nosso Cotidiano. São Paulo, Saraiva, 2003.
} 
to, a (Fatura Comercial) do Chinês não corresponde à Nota Fiscal do português.

Por vezes, esse obstáculo pode causar problemas pequenos, entretanto, causam também malentendimento graves. Como tinha mencionado no início, em 2003, 6,4 milhões de toneladas de soja foram enviadas à China. Desse total, 1,6 milhões eram de grãos não qualificados. Um grande número de trabalhadores chineses teve de ser mobilizado apenas para selecionar a soja com problema para a China não ter que devolver toda a soja para o Brasil. Então se houvesse uma comunicação efetiva e direta entre duas línguas, seria possível evitar esta perda de tempo e mão-de-obra.

Uma outra realidade inescapável é que ambos povos destes dois países não são tão proficientes no domínio da língua inglesa. A percentagem da população que fala inglês dos dois países é baixa e não mudará em curto prazo. Por isso, torna-se uma "missão impossível" para dois povos comunicarem-se eficientemente através de uma terceira língua, estrangeira para ambos.

Enfim, os contatos imensos entre o Brasil e a China, e o obstáculo de inglês demandam a comunicação direta entre os dois países. Isto cria a necessidade de dicionários de português e chinês em diversas áreas.

\subsection{Consultas aos especialistas}

Os terminólogos são antes de tudo especialistas em lingüística, e podem não ter um conhecimento suficiente na área especializada a que sua obra pertence. Por outro lado, mesmo que um terminólogo seja um especialista de área, suas opiniões próprias podem influenciar a precisão da definição dos termos. Por isso, é indispensável a consulta de outros especialistas desta área para a obra fica mais racional e justa.

Para determinar definições adequadas e realmente usadas na área do co- 
mércio exterior, consultei vários especialistas chineses e brasileiros quem trabaIham com finanças, importação e exportação. As informações detalhadas sobre os informantes são as seguintes:

\section{Zheng Cui}

Profissão e cargo: bancário, representante do Banco da China no Brasil

Formação: Mestrado em Finanças empresariais na FEA - Faculdade de Econômia, Administração e Contabilidade da USP - Universidade de São Paulo;

Graduação em Língua Portuguesa da Faculdade de Espanhol e Português da Universidade de Estudos Estrangeiros de Pequim.

Experiência: na área financeira: 6 anos.

\section{Sónia Bochnia:}

Profissão e cargo: Especialista na Importação e Exportação na MINIPA Indústria e Comércio Ltda. (Empresa industrial e comercial de instrumentos de medição e de equipamentos didáticos do Brasil)

Formação: Bacharel de Administração/Especialidade Turismo

Experiência: na área de comércio exterior: 22 anos;

\section{Wenyu Zou}

Profissão e cargo: Gerente comercial da Huawei Technologies Co. Ltd. no Brasil Formação: Graduação em Business English da Faculdade de Inglês da Universidade de Estudos Estrangeiros de Pequim

Experiência: na área comercial: 6 anos

\section{GLOSSÁRIO TERMINOLÓGICO DE COMÉRCIO EXTERIOR}

\subsection{Apresentação}


O presente glossário contém 62 termos na direção do chinês ao português e 64 termos do português ao chinês. São termos mais freqüêntes coletados dos documentos de comércio exterior. Os documentos de referência estão no anexo desta dissertação.

As abreviaturas utilizadas no glossário são seguintes:

Informação gramatical:

[s] substantivo

[v] verbo

[adj] adjetivo

[adv] advérbio

Informação da língua:

PT - português

$\mathrm{CHN}$ - chinês

ING - inglês

\section{2 Índice remissivo e texto de glossário (chinês-português) \\ Chinês - Português}


A

B

Bào Guān

Bào Guān Yuán $\quad$........................................................................ 80

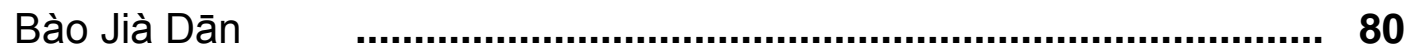

Bèi Shū

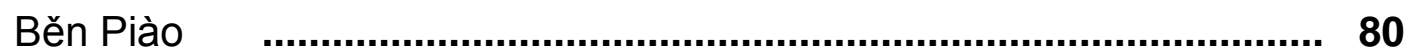

Bǔ Jié Tí Dān $\quad$............................................................................. 81

C

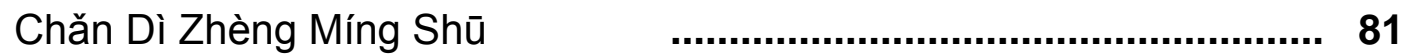

Chéng Běn Băo Xiăn Jiā Yùn Fèi

Chéng Bèn Jiā Yùn Fèi

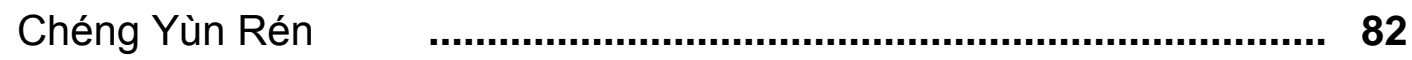

Chū Kǒu Băo Xiăn

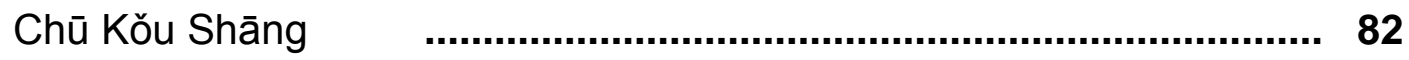

Chū Kǒu Xǔ Kě Zhèng

Chuán Shàng Jiāo Huò $\quad$.............................................................. 83

Chuán Zhăng Cāng Dān $\quad$............................................................... 83

D

Diàn Huì

Dìng Huò Dān $\quad \ldots$

Duō Shì Lián Yùn Tí Dān $\quad$..................................................... 84

E

$\mathbf{F}$

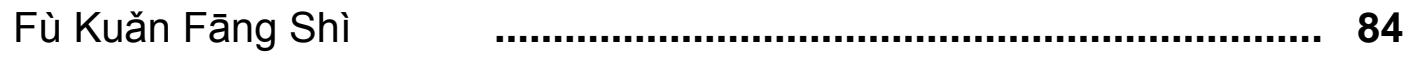

G

Gēn Dān Tuō Shōu 
Gēn Dān Xìn Yòng Zhèng

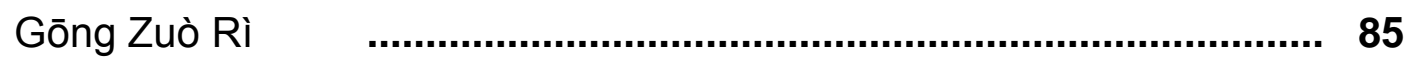

Gòu Huò Hé Tóng

Guān Shuì

\section{H}

Hăi Guān

Hăi Guān Fā Piào $\quad$..................................................................... 86

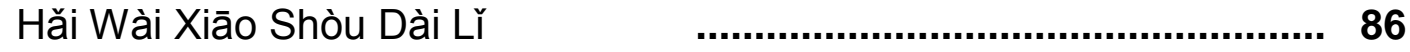

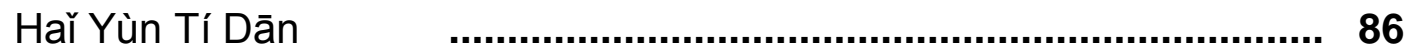

Háng Kōng Yùn Dān $\quad$.............................................................. 87

Huì Kuăn

Huì Piào

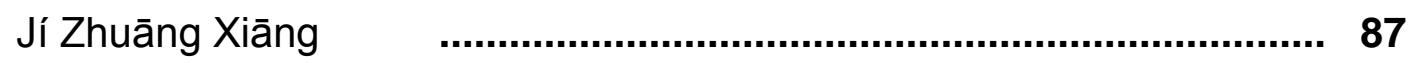

Jí Zhuāng Xiāng Cháng Shōu Jù

Jìn Kǒu Huò Wù Bào Guān Dān

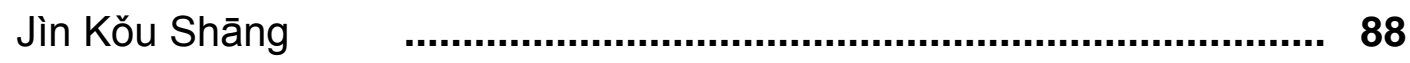

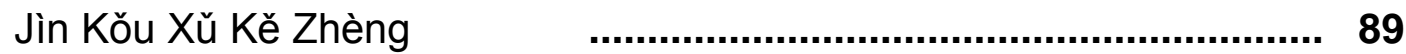

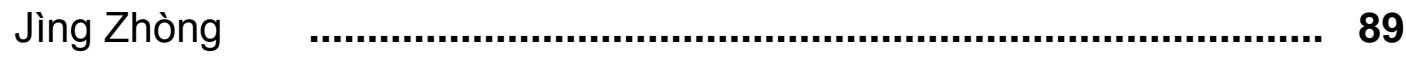

K

$\mathbf{L}$

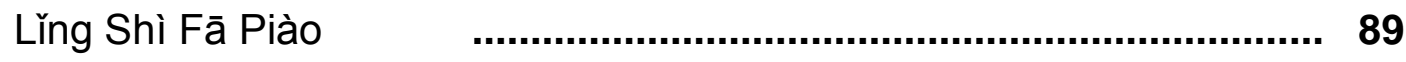

Lù Yùn Tí Dān $\quad \ldots$

M

Máo Zhòng 
0

$\mathbf{P}$

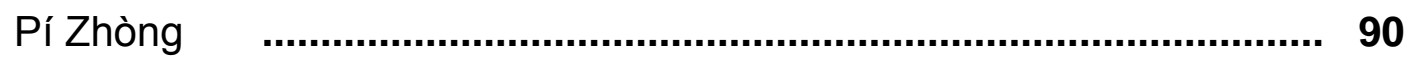

Piào Huì $\quad$.................................................................................. 90

Q

Qīng Jié Tí Dān $\quad$........................................................................ 90

Quán Chéng Tí Dān $\quad$............................................................ 90

$\mathbf{R}$

S

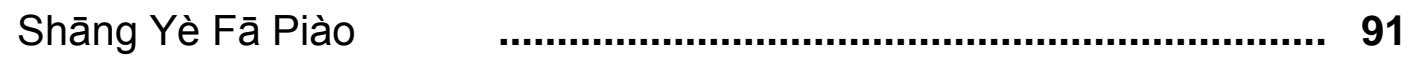

$\mathbf{T}$

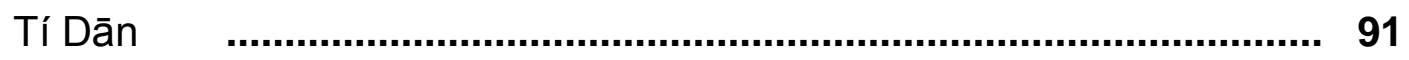

Tiě Lù Tí Dān $\quad$................................................................... 92

Tuō Shōu $\quad$.................................................................................... 92

$\mathbf{U}$

V

$\mathbf{W}$

Wèi Shēng Jiăn Yàn Zhèng Shū $\quad$...................................... 92

$\mathbf{X}$

Xìn Huì

92

Xìn Yòng Zhèng $\quad$...................................................................... 93

Xíng Shì Fā Piào $\quad$..................................................................... 93 
Yĩ Zhuāng Chuán

Yî Zhuāng Shàng Jiă Băn

Yín Háng Băo Zhèng Shū

Yù Fù Kuăn

Yùn Fèi

Yùn Fèi Fù Zhì

Yùn Fèi Jiā Băo Xiăn Fèi

Yùn Shū Dān Jù

Zhòng Liàng Dān

96

Zhuāng Xiāng Dān

96

1. (Bào Guān) [s]

PT: Despacho aduaneiro

ING: Entry

Procedimento para o desembaraço aduaneiro de mercadorias destinadas ou recebidas do exterior na alfândega. Inclui declaração de conteúdo e valor de mercadorias e pagamento de tarifas aduaneiras.

2. (Bào Guān Yuán) [s]

PT: Despachante aduaneiro

ING: Customs broker

Profissional que providencia a documentação e acompanha, junto à 
alfândega, a liberação de mercadorias importadas ou a exportar, expressamente autorizado pela empresa interessada.

3. (Bào Jià Dān) [s]

PT: Lista de Preços / Cotação de Preço

ING: Quotation Sheet

Um documento, onde consta a relação de itens, que o comprador quer que sejam cotados, e seus respectivos preços.

4. (Bèi Shū) $[s]$

PT: Endosso / endossamento

ING: Endorsement

Transferência da propriedade de um título mediante declaração escrita, geralmente feita em seu próprio verso.

5. (Běn Piào) [s]

PT: Nota promissória

ING: Promissory note, P/N.

(título negociável); também conhecida pela abreviatura I.O.U., que significa I owe you (eu devo a você).

6. (Bǔ Jié Tí Dān) [s]

PT: Conhecimento de embarque "sujo"

ING: Foul bill of lading

Conhecimento de embarque com notação feita pelo transportador indicando que a mercadoria estava avariada quando recebida para embarque.

Ver (Conhecimento de embarque limpo).

7. (Chăn Dì Zhèng Míng Shū) [s] 
PT: Certificado de Origem.

ING: Certificate of origin

Documento que atesta a origem da mercadoria e comprova o país de origem das mercadorias transacionadas no mercado internacional.

8.

(Chéng Běn Băo Xiăn Jiā Yùn Fèi) [s]

PT: Custo, seguro e frete - porto de embarque indicado

ING: CIF - Cost, insurance and freight (named port of destination)

Condição dos Incoterms 2000, em que a cotação dada para a mercadoria vendida inclui seu custo, mais o frete e o seguro até o ponto de chegada. Exemplo: CIF Shanghai, inclui o custo da mercadoria, mais o seguro e o frete até o porto de Shanghai. Termo utilizável exclusivamente no transporte marítimo. A responsabilidade do vendedor cessa assim que a mercadoria transpõe a amurada do navio.

9.

(Chéng Běn Jiā Yùn Fèi) [s]

PT: Custo e frete - porto de embarque indicado

ING: CFR - Cost and freight (named port of destination)

Incoterms 2000, da Câmara de Comércio Internacional (ICC). Esse termo significa que o vendedor contrata e paga o frete necessário para levar a mercadoria até o porto de destino indicado, além de providenciar os documentos e preparar a carga para exportação. Termo utilizável exclusivamente no transporte marítimo. A responsabilidade sobre a mercadoria e quaisquer despesas adicionais é transferida do vendedor para o comprador no momento da transposição da amurada do navio no porto de embarque.

10. (Chéng Yùn Rén) [s]

PT: Transportador

ING: Carrier 
Empresa que responsabiliza-se pelo transporte de mercadoria.

11. (Chū Kǒu Băo Xiăn) [s]

PT: Seguro de exportação

ING: Export Insurance

Garante ao exportador a indenização por perdas líquidas definitivas, em conseqüência do não recebimento de crédito consedido a cliente no exterior. Adicionalmente, funciona também como instrumento de prevenção, como incentivo para prospecção de novos clientes e novos mercados e ainda como ferramenta de cobrança.

12. (Chū Kǒu Shāng) [s]

PT: Exportador

ING: Exporter

Indivíduo ou empresa que vende - exporta - ao exterior bens ou serviços.

13. (Chū Kǒu Xǔ Kě Zhèng) [s]

PT: Licença de Exportação

ING: Export license

Como o próprio nome diz, é um documento expedido por um órgão governamental, que habilita o exportador a realizar a operação. Neste documento em geral, ser especifica, quais as mercadorias, importador e exportador e todos os dados pertinentes à operação.

14.

(Chuán Shàng Jiāo Huò) [s]

PT: Livre a bordo - porto de embarque indicado.

ING: FOB - Free on board (named port of shipment)

Termo dos Incoterms 2000 que indica que a quotação inclui o custo da mercadoria mais as despesas para colocá-la a bordo. Outras despesas, tais como frete e seguro, são de responsabilidade do 
comprador. Nesse momento, o comprador assume todas as responsabilidades. Termo utilizável exclusivamente no transporte marítimo.

15. (Chuán Zhăng Cāng Dān) [s]

PT: Manifesto do embarcador

ING: Shipping manifest / ship's manifest

Instrumento escrito, assinado pelo capitão do navio, que lista individualmente os embarques que constituem a carga embarcada.

16. (Diàn Huì) [s]

PT: Transferência telegráfica

ING: Telegraphic transfer - T/T

Remessa de valores em pagamento por telegrama, SWIFT.

17. (Dìng Huò Dān) [s]

PT: Ordem de Compra

ING: Purchase Order

Documento de pedido de compra em que comprador encomenda a mercadoria a vendedor. Nesse documento contem nome e quantidade de mercadoria e condições aceitadas pelo comprador, para o recebimento do bem.

18.

(Duō Shì Lián Yùn Tí Dān) [s]

PT: Conhecimento de embarque intermodal

ING: Multimodal tranporte document/ combined bill of lading Conhecimento de embarque relativo a mercadorias em cuja entrega são utilizados vários tipos de transportes.

19. (Fù Kuăn Fāng Shì) [s]

PT: Forma de pagamento

ING: Payment methods 
Em comércio internacional, tem diversos métodos ou modalidades de pagamento tais como Anticipado, Cobrança documentária, Cobrança sem saque e Carta de Crédito.

20. (Gēn Dān Tuō Shōu) [s]

PT: Cobrança documentária

ING: Documentary collection

Cobrança amparada em documentos comerciais e financeiros ou acompanhada de documentos comerciais. Esses documentos podem ser representados por cheques, títulos ou qualquer outro que represente documento financeiro.

21. (Gēn Dān Xìn Yòng Zhèng) [s]

PT: Carta de crédito documentário

ING: Documentary letter of credit

Um dos dois tipos de Carta de crédito. É carta de crédito acompanada com documentos.

22. (Gōng Zuò Rì) [s]

PT: Dia útil

ING: Working day / Business day

Dia de funcionamento das empresas e entidades.

23. (Gòu Huò Hé Tóng) [s]

PT: Contrato de compra

ING: Purchase contract

Instrumento especial firmado entre vendedor (exportador) e comprador (importador) no qual contém cláusulas que estabelecem as condições (obrigações e deveres) para negociação de compra de mercadoria. 
24. (Guān Shuì) [s]

PT: Tarifas aduaneiras

ING: Customs duties

Taxas pagas sobre os direitos de importação e exportação, transporte de carga e prestação de serviços em geral.

25. (Hăi Guān) [s]

PT: Alfândega

ING: Customs

Repartição governamental que fiscaliza a entrada e saída de mercadorias em cada país, para assegurar o pagamento das tarifas correspondentes e o cumprimento das normas locais de comércio internacional. Cumpre também à alfândega impedir a prática de contrabando e a entrada no país de mercadorias consideradas contrárias aos interesses da produção nacional.

26. (Hăi Guān Fā Piào) [s]

PT: Fatura aduaneira ou alfandegária.

ING: Customs invoice

Fatura feito de um formulário especial pelas autoridades aduaneiras de país de importação. Utilizado em poucos países.

27. (Hăi Wài Xiāo Shòu Dài Lǐ) [s]

PT: Representante de venda no estrangeiro

ING: Foreign sales agent

Pessoa ou empresa que atua como representante externo de um fornecedor doméstico e procura vender no exterior os ítens manufaturados pelo fornecedor.

28. (Haì Yùn Tí Dān) [s]

PT: Conhecimento de embarque marítimo 
ING: Ocean bill of lading - B/L

Conhecimento de embarque certifica que o exportador confiou a transportador internacional sua mercadoria para transporte a outro país. Diferente do Conhecimento Interno (doméstico), o conhecimento marítimo vale como documento de cobrança. É um conhecimento quando o comprador obtém esse documento apenas identificando-se perante o transportador. É chamado "negociável" quando este só é obtido após o pagamento da mercadoria, aceita uma cobrança ou cumpre com outras exigências acordadas com o vendedor. É um recibo de mercadorias, um contrato de entrega e um documento de propriedade.

Na China, é chamado diretamento como " "

29. (Háng Kōng Yùn Dān) [s]

PT: Conhecimento de embarque aéreo

ING: Airway bill; Air waybill

É um conhecimento de embarque que cobre simultaneamente os vôos domésticos e internacionais de mercadorias a um destino específico. Um não-negociável instrumento de transporte aéreo funciona como um recibo para o expedidor e indica que o transportador aceitou as mercadorias discriminadas e obrigou-se a transportar a mercadoria despachada até o aeroporto de destino, sob condições especificadas. É um recibo de mercadorias, um contrato de entrega mas não é um documento de propriedade.

É nomeado também como " "

30. (Huì Kuăn) [s]

PT: Remessa / tranferência de fundos

ING: Remittance

Remessa de valores em pagamento de aquisição de mercadorias ou serviços. 
31. (Huì Piào) [s]

PT: Saque / Cambial

ING: Draft / bill of exchange

É um título de crédito sacado por um credor contra um devedor, com ordem expressa para que o devedor pague certa quantia a determinada pessoa, ou a sua ordem, em determinado prazo e em local determinado.

32. (Jí Zhuāng Xiāng) [s]

PT: Contêiner / Cofre de carga

ING: Container

Recipientes metálicos para transporte de mercadoria. São internacionalmente padronizados, com altura e largura de 8 pés e comprimentos que variam entre 5, 10, 20, 30 e 40 pés, apresentando como principais vantagens a inviolabilidade, redução de $10 \%$ no frete marítimo e taxas especiais para o transporte rodoferroviário, prêmios de seguros menores e livre trânsito em todo o território nacional. $O$ sistema de embalagem de mercadorias em recipientes metálicos para o transporte, o que aumenta a velocidade de embarque e desembarque, reduzindo, portanto, os custos de transporte.

33.

\section{(Jí Zhuāng Xiāng Cháng Shōu Jù) [s]}

PT: Recibo de cais

ING: Dock receipt - D/R

Recibo emitido por transportador marítimo reconhecendo o recebimento de mercadoria para embarque em seu próprio cais ou em armazém apropriados.

34. (Jìn Kǒu Huò Wù Bào Guān Dān) [s]

PT: Formulário de declaração de carga de importação 
ING: Import cargo declaration sheet

Formulário exigido pela Alfândega da China para todas as mercadorias de importação destinados à China, com indicação de valor, peso, origem, destino final e outros detalhes do produto embarcado e desembarcado.

35. (Jìn Kǒu Shāng) [s]

PT: Importador

ING: Importer

Indivíduo ou empresa que compra mercadorias ou serviços no exterior, trazendo-os para venda no mercado doméstico.

36. (Jìn Kǒu Xŭ Kě Zhèng) [s]

PT: Licença de Importação

ING: Import license

Documento requerido e emitido por departamento aduaneiro de alguns países autorizando a importação de mercadorias.

37. (Jìng Zhòng) [s]

PT: Peso líquido

ING: Net weight

Peso de mercadoria sem embalagem.

38. (Lìng Shì Fā Piào) [s]

PT: Fatura consular

ING: Consular invoice

Documento exigido por alguns países que menciona detalhes da mercadoria embarcada, tais como: nome do consignador, consignatário, valor da mercadoria etc. Autenticado por um representante consular do país do importador, é utilizado com propósitos alfandegários, no controle do preço da mercadoria, quantidade e procedên- 
cia do embarque.

39.

(Lù Yùn Tí Dān) [s]

PT: Conhecimento de embarque interno-doméstico

ING: Inland bill of lading

Conhecimento de embarque utilizado para transporte interno no país do exportador pelo transportador. Um não-negociável instrumento funciona como um recibo de mercadorias, um contrato de entrega mas não é um documento de propriedade.

40. (Máo Zhòng) [s]

PT: Peso bruto

ING: Gross weight

Peso total de mercadoria com embalagem.

41. (Pí Zhòng) [s]

PT: Tara

ING: Tara / Tare weight

Peso do contêiner, embalagem ou veículo transportador sem o peso da mercadoria. É a diferença entre o peso total (peso bruto) de uma carga e o peso (líquido) das mercadorias que são transportadas.

42. (Piào Huì) [s]

PT: Transferência de saque

ING: Demand draft - D/D

Pagamento contra apresentação de saque.

43. (Qīng Jié Tí Dān) [s]

PT: Conhecimento de embarque limpo

ING: Clean bill of lading

Conhecimento de embarque com marcação pelo transportador indi- 
cando que mercadorias foram recebidas "em aparente ordem e condições", sem danos ou outras irregularidades. Entende-se que a mercadoria foi conferida e achada em ordem pelo transportador.

44. (Quán Chéng Tí Dān) [s]

PT: Conhecimento de embarque direto/Conhecimento único

ING: Through bill of lading

Conhecimento com transbordo, utilizado no transporte intermodal, que cobre o transporte interno (doméstico) e internacional em um embarque de exportação.

45. (Shāng Yè Fā Piào) [s]

PT: Fatura comercial

ING: Commercial invoice

1) Documento que comprova a venda da mercadoria e que transfere ao comprador sua posse, não propriedade. Documento usado internacionalmente para comprovar a venda mercantil. Nela devem aparecer todos os detalhes possíveis da operação: nome do vendedor, endereço, nome do comprador e endereço, nome do consignatário (que poderá ser o comprador), nome do representante e, de uma forma sumária, as condições em que foi efetuada a venda, tais como: prazo, modalidade de pagamento (nesse caso, cobrança bancária) etc. A Fatura Comercial deverá incorporar todos os dados da Fatura Pró-forma, que é o documento que dá origem ao negócio.

2) Documento internacional, emitido pelo exportador, que, no âmbito externo, equivale à nota fiscal, cuja validade começa a partir da saída da mercadoria do território nacional e é imprescindível para o importador desembaraçar a mercadoria em seu país. Documento contábil que comprova a venda de uma mercadoria ou de um serviço. Como os impostos são cobrados sobre os valores registrados nas faturas, elas são documentos que permitem a circulação das mercadorias. 
46. (Tí Dān) [s]

PT: Conhecimento de embarque marítimo

ING: Ocean bill of lading - B/L

Conhecimento de embarque ou de transporte e que consiste num documento que o responsável pelo transporte de uma mercadoria por navio, entrega ao seu proprietário, declarando que ela foi recebida para transporte até um determinado destino, estabelecendo as condições sob as quais essa mercadoria está sendo transportada. É ao mesmo tempo um recibo de mercadorias, um contrato de entrega e um documento de propriedade. Este termo é somente usada para transporte marítimo. Ver "

47. (Tiě Lù Tí Dān) [s]

PT: Conhecimento de embarque ferroviário

ING: Railway bill

É um conhecimento de embarque cobre transporte de mercadorias por trem a um destino específico. Um não-negociável instrumento funciona como um recibo de mercadorias, um contrato de entrega mas não é um documento de propriedade.

48. (Tuō Shōu) [s]

PT: Cobrança em exportação

ING: Collection

1) Cobrança documental ou financeira, de acordo com o art. $2^{\circ}$ das Regras Uniformes para Cobrança (URC522), da Câmara Internacional do Comércio.

2) Entrega ao banco, para cobrança do importador no exterior, dos documentos de embarque, incluindo conhecimento de embarque, faturas, saque cambial, romaneio e outros que possam ser exigidos como certificados de origem, fitossanitário, entre outros.

49. (Wèi Shēng Jiăn Yàn Zhèng Shū) [s]

PT: Certificado de Inspeção Sanitária

ING: Sanitary Inspection Certificate 
Certificado emitido pelas autoridades sanitárias para atender a regulamentação sanitária nos países importadores; indica que o embarque foi inspecionado e encontra-se em boas condições, sem risco de doenças ou outras infecções parasitárias.

50. (Xìn Huì) [s]

PT: Ordem de pagamento por via postal

ING: Mail transfer - M/T

Remessa de valores em pagamento por via postal.

51. (Xìn Yòng Zhèng) [s]

PT: Carta de crédito

ING: Letter of credit - L/C

Documento emitido por um banqueiro, por solicitação e instrução de um cliente, autoriza o destinatário a entregar a uma terceira pessoa certa importância em dinheiro ou determinada quantidade de mercadorias, mediante certas condições. A entrega se faz sob a garantia do signatário (banqueiro), de forma que ele exerça o papel de fiador da operação. Pode ser entendida como uma ordem de pagamento realizável contra entrega de determinadas mercadorias em determinadas condições, como é seu uso comum no comércio exterior.

52. (Xíng Shì Fā Piào) [s]

PT: Fatura Pró-forma/proforma

ING: Pro forma invoice

Fatura emitida a pedido do importador em caráter preliminar com todas as caraterísticas (preço unitário, prazo, condições de pagamento, nomes e endereços do comprador e vendedor etc.) da fatura definitiva. Serve para formalizar e confirmar a negociação, mas não implica pagamento por parte do comprador. É geralmente emitida para atender a determinações de autoridades aduaneiras. Aceita e 
assinada pelo comprador, representa o contrato de compra e venda.

53. (Yĩ Zhuāng Chuán) [s]

PT: A bordo

ING: On board

Uma notação de "a bordo" num conhecimento de embarque pela qual o transportador atesta que a mercadoria foi colocada a bordo de determinado navio.

54.

(Yĩ Zhuāng Shàng Jiǎ Băn) [s]

PT: No convés

ING: On deck

Uma notação de "no convés" num conhecimento de embarque que indica a mercadoria foi colocada no convés de determinado navio.

55. (Yín Háng Băo Zhèng Shū) [s]

PT: Carta de garantia bancária

ING: Banker's letter of guarantee - L/G; Letter of guaranty; Bank guarantee

Garantia bancária em que o banco se responsabiliza pelo pagamento se o garantidor não cumpre o contratado.

56. (Yù Fù Kuăn) [s]

PT: Pagamento antecipado

ING: Advanced payment

Um dos métodos de pagamento em comércio exterior internacional, em que o comprador paga antecipadamente antes de remeter-se a mercadoria. Método utilizado para transações de pequeno valor, em mercadorias feitas sob encomendas a título de sinal e, quando o comprador/importador não tem tradição com o vendedor/exportador. Ver (forma de pagamento). 
57. (Yùn Fèi) [s]

PT: Frete

ING: Freight

Preço do transporte de mercadoria até o seu destino, via aérea, rodoviária ou aquática, que não bagagem, correio expresso ou correio normal. O preço do frete costuma constar nos conhecimentos de embarque, e a cláusula CIF nos preços das mercadorias indica que estes incluem o frete, o custo e o seguro.

58.

(Yùn Fèi Fù Zhì) [s]

PT: Transporte pago até - porto de embarque indicado

ING: CPT - Carriage paid to (named port of destination)

Termo dos Incoterms 2000 significando que o vendedor paga o frete pelo transporte das mercadorias até o destino designado. O risco por perda ou dano às mercadorias, bem como quaisquer despesas adicionadas devidas a eventos que ocorram após terem sido as mercadorias entregues ao transportador, transferem-se do vendedor ao comprador quando as mercadorias são entregues à custódia do transportador. Termo utilizado em qualquer modalidade de transporte.

59.

(Yùn Fèi Jiā Băo Xiăn Fèi) [s]

PT: Transporte e seguro pagos até - Porto de embarque indicado ING: CIP - Carriage and insurance paid to (named port of destination)

Termo dos Incoterms 2000, signifiando que o vendedor tem as mesmas obrigaçoes inerentes ao termo CPT; todavia, com a responsabilidade de providenciar o seguro da carga contra risco de perda ou dano, em favor do comprador, durante o transporte. O vendedor contrata o seguro e paga o respectivo prêmio. Termo pode ser utili- 
zado em qualquer modalidade de transporte.

60. (Yùn Shū Dān Jù) [s]

PT: Conhecimento de embarque

ING: Transport documents

Conhecimento de embarque ou de transporte e que consiste num documento que o responsável pelo transporte de uma mercadoria, por trem, navio, avião, caminhão, entre outros, entrega ao seu proprietário, declarando que ela foi recebida para transporte até um determinado destino, estabelecendo as condições sob as quais essa mercadoria está sendo transportada. Tem conhecimento de embarque negociável e não negociável. Os conhecimento de embarque aéreo e ferroviário são não negociáveis, é somente um recibo de mercadoria e um contrato de entrega. O conhecimento de embarque marítimo é negociável, e é nomeado como “" "ou “" ". É ao mesmo tempo um recibo de mercadorias, um contrato de entrega e um documento de propriedade. Em geral, quando não tem indicação específica, conhecimento de embarque significa conhecimento de embarque marítimo.

61. (Zhòng Liàng Dān) [s]

PT: Lista de peso

ING: Weight list

Documento emitido pelo exportador, em alguns casos, discriminando o peso líquido e bruto de cada volume, não sendo, porém, de emissão muito freqüente em face da existência desses dados no próprio romaneio (packing list).

62. (Zhuāng Xiāng Dān) [s]

PT: Romaneio/lista de mercadorias/romaneio de embarque ING: Packing list 
É uma simples relação, indicando os volumes que devem ser embarcados e respectivas caraterísticas como número, peso e marca. Destinada a auxiliar a identificação e a fiscalização de volumes e desembaraços aduaneiros.

\section{3 Índice remissivo e texto de glossário (português-chinês)}

\section{Português - Chinês}

\section{A}

A bordo

101

Alfândega

B

C

Carta de crédito

101

Carta de crédito documentário 101

Carta de garantia bancária 101

Certificado de inspeção 102

Certificado de origem 102

Certificado sanitário 102

Cobrança 103

Cobrança documentária 103

Conhecimento de embarque 103

Conhecimento de embarque aéreo 103

Conhecimento de embarque direto 104

Conhecimento de embarque intermodal 104

Conhecimento de embarque interno-doméstico 104

Conhecimento de embarque limpo 104

Conhecimento de embarque marítimo 105

Conhecimento de embarque "sujo" 105

Contêiner 105 
Contrato

Contrato de compra 106

Cotação de preço 106

Custo e frete - porto de embarque indicado 106

Custo, seguro e frete - porto de embarque indicado 106

Despachante aduaneiro 107

Despacho aduaneiro 107

Dia útil 107

\section{E}

$\mathbf{F}$

Endosso 107

Exportador 107

Fatura aduaneira 108

Fatura comercial 108

Fatura consular 108

Fatura Pró-forma/proforma 109

Forma de pagamento 109

Formulário de Declaração de Carga de Importação 109

Frete 109

G

H

I

Importador 109

ICMS - Imposto sobre a Circulação de Mercadorias e Serviços .... 110 IPI - Imposto sobre Produtos Industrializados 
Licença de Exportação ….............................................................. 110

Licença de Importação ............................................................... 110

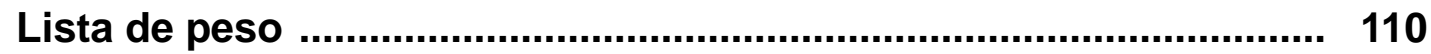

Livre a bordo - porto de embarque indicado .................................... 111

M

Manifesto do embarcador ............................................................... 111

$\mathbf{N}$

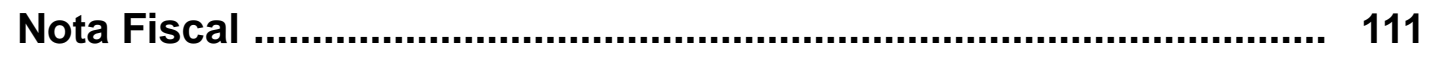

Nota promissória ……................................................................... 111

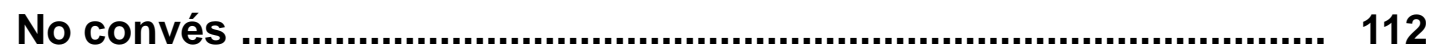

o

Ordem de Compra ….................................................................. 112

Ordem de pagamento por via postal ............................................ 112

\section{$\mathbf{P}$}

Pagamento antecipado ................................................................... 112

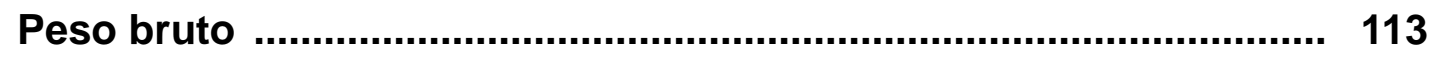

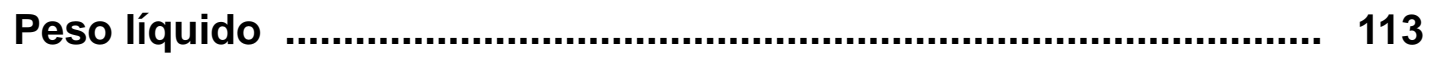

$\mathbf{R}$

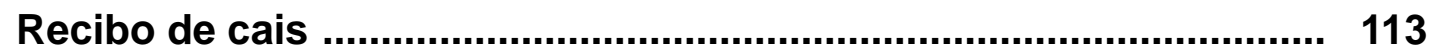

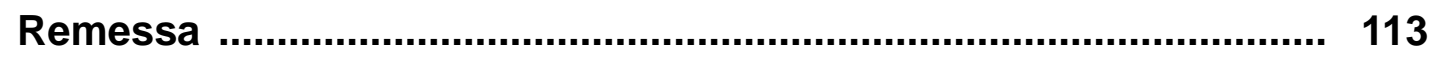

Representante de venda no estrangeiro ....................................... 113

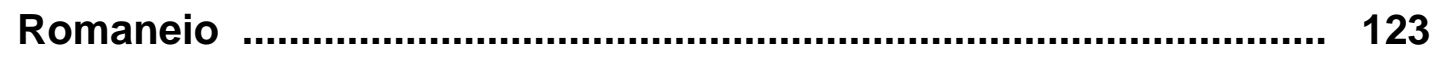

\section{S}

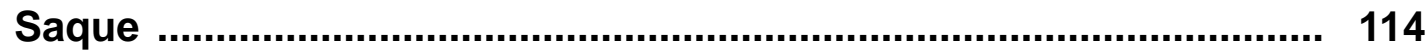




\section{$\mathbf{T}$}

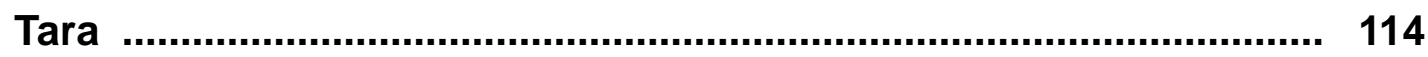

Tarifas aduaneiras

Transferência telegráfica ............................................................. 115

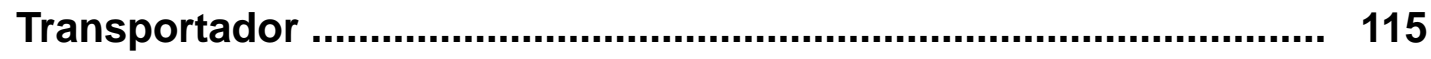

Transporte e seguro pagos até - porto de embarque indicado ....... 115

Transporte pago até - porto de embarque indicado ........................ 115

U
V
$W$
$X$
$Y$
$Z$ 
1. A bordo [ ]

CHN: (Yĩ Zhuāng Chuán)

ING: On board

،,

2. Alfândega [ ]

CHN: (Hăi Guān)

ING: Customs

3. Carta de crédito [ ]

CHN: (Xìn Yòng Zhèng)

ING: Letter of credit - L/C

4. Carta de crédito documentário [ ]

CHN: $\quad$ (Gēn Dān Xìn Yòng Zhèng)

ING: Documentary letter of credit

5. Carta de garantia bancária [ ]

CHN: $\quad$ (Yín Háng Băo Zhèng Shū) 
ING: Banker's letter of guarantee - L/G; Letter of guaranty; Bank guarantee

6. Certificado de inspeção [ ]

CHN: $\quad$ (Shāng Pìn Jiǎn Yàn Zhèng Shū)

ING: Inspection Certificate

7. Certificado de origem [ ]

CHN: $\quad$ (Chăn Dì Zhèng Míng Shū)

ING: Certificate of origin

8. Certificado sanitário [ ]

CHN: (Wèi Shēng Zhèng Míng Shū)

ING: Sanitary inspection certificate

9. Cobrança [ ]

CHN: (Tuō Shōu)

ING: Collection 
10. Cobrança documentária [ ]

CHN: $\quad$ (Gēn Dān Tuō Shōu)

ING: Documentary collection

I 1

11. Conhecimento de embarque [ ]

CHN: (Yùn Huò Dān) / (Tí Dān)

ING: Transport documents / Bill of lading

\begin{tabular}{lcrrrr}
\multicolumn{2}{c}{ Conhecimento } & \multicolumn{2}{c}{ de } & embar- \\
que & $/$ & (Conhecimento de & embarque \\
aéreo) & (Conhecimento & de & embarque & marítimo) \\
& (Conhecimento & de & embarque & ferroviá-
\end{tabular}

rio) Conhecimento de embarque

12. Conhecimento de embarque aéreo [ ]

CHN: $\quad$ (Háng Kōng Yùn Dān)

ING: Airway bill; Air waybill

13. Conhecimento de embarque direto [ ]

CHN: $\quad$ (Quán Chéng Tí Dān)

ING: Through bill of lading

“Conhecimento único” 
14. Conhecimento de embarque intermodal [ ] CHN: $\quad$ (Duō Shì Lián Yùn Tí Dān)

ING: Combined bill of lading

15. Conhecimento de embarque interno-doméstico [ ] CHN: (Lù Yùn Tí Dān) ING: Inland bill of lading

16. Conhecimento de embarque limpo [ ] CHN: $\quad$ (Qīng Jié Tí Dān) ING: Clean bill of lading

17. Conhecimento de embarque marítimo [ ] CHN: (Haĩ Yùn Tí Dān) ING: Ocean bill of lading - B/L

18. Conhecimento de embarque "sujo" [ ] CHN: (BǔJié Tí Dān) ING: Foul bill of lading 
19. Contêiner [ ]

CHN: (Jí Zhuāng Xiāng)

ING: Container

“ ”

$10 \quad 20 \quad 30 \quad 40$

20. Contrato [

CHN: (Hé Tóng)

ING: Contract

21. Contrato de compra [ ]

CHN: (Gòu Huò Hé Tóng)

ING: Purchase contract

22. Cotação de preço [ ] ]

CHN: (Bào Jià Dān)

ING: Quotation Sheet

23. Custo e frete - porto de embarque indicado [ ]

CHN: (Chéng Bèn Jiā Yùn Fèi)

ING: CFR - Cost and freight (named port of destination)

2000 
24. Custo, seguro e frete - porto de embarque indicado [ ] CHN: $\quad$ (Chéng Běn Băo Xiăn Jiā Yùn Fèi)

ING: CIF - Cost, insurance and freight (named port of destination) 2000 CFR

25. Despachante aduaneiro [ ]

CHN: (Bào Guān Yuán)

ING: Customs broker

26. Despacho aduaneiro [

CHN: (Bào Guān)

ING: Entry / Customs clearance

27. Dia útil [ ]

CHN: $\quad$ (Gōng Zuò Rì)

ING: Working day / Business day

28. Endosso [ ]

CHN: (Bèi Shū)

ING: Endorsement 
29. Exportador [ ]

CHN: (Chū Kǒu Shāng)

ING: Exporter

30. Fatura aduaneira [ ]

CHN: (Hăi Guān Fā Piào)

ING: Customs invoice

31. Fatura comercial [ ]

CHN: (Shāng Yè Fā Piào)

ING: Commercial invoice

1)

2)

32. Fatura consular [ ]

CHN: $\quad$ (Lǐng Shì Fā Piào)

ING: Consular invoice

33. Fatura Pró-forma/proforma [ ]

CHN: (Xíng Shì Fā Piào)

ING: Pro forma invoice 
34. Forma de pagamento [ ]

CHN: $\quad$ (Fù Kuăn Fāng Shì)

ING: Payment methods

35. Formulário de Declaração de Carga de Importação [ ]

CHN: (Jìn Kǒu Huò Wù Bào Guān Dān)

ING: Import Cargo Declaration Sheet

36. Frete [ ]

CHN: (Yùn Fèi)

ING: Freight

37. Importador [ ]

CHN: (Jìn Kǒu Shāng)

ING: Importer

38. ICMS - Imposto sobre a Circulação de Mercadorias e Serviços [ CHN: $\quad$ (Shāng Pìn Fú Wù Líu Tōng Shuì)

ING: Merchandise and Service Circulation Tax 
39. IPI - Imposto sobre Produtos Industrializados [ ]

CHN: $\quad$ (Gōng Yè Chăn Pìn Shuì)

ING: Industrialized Product Tax

40. Licença de Exportação [ ] ]

CHN: (Chū Kǒu Xǔ Kě Zhèng)

ING: Export license

41. Licença de Importação [ ]

CHN: (Jìn Kǒu Xǔ Kě Zhèng)

ING: Import license

42. Lista de peso [ ]

CHN: $\quad$ (Zhòng Liàng Dān)

ING: Weight list

43. Livre a bordo - porto de embarque indicado [ ]

CHN: (Chuán Shàng Jiāo Huò)

ING: FOB - Free on board (named port of shipment)

2000

11 
44. Manifesto do embarcador [ ]

CHN: (Chuán Zhăng Zhàng Dān)

ING: Shipping manifest / ship's manifest

45. Nota Fiscal [ ]

CHN: (Shuì Shōu Piào Jù)

ING:

46. Nota promissória [ ]

CHN: (Běn Piào)

ING: Promissory note, $\mathrm{P} / \mathrm{N}$.

47. No convés [ ]

CHN: (Yĩ Zhuāng Shàng Jiǎ Băn)

ING: On deck

48. Ordem de Compra [ ]

CHN: $\quad$ (Dìng Huò Dān)

ING: Order

6996 
49. Ordem de pagamento por via postal [

CHN: (Xìn Huì)

ING: Mail transfer - M/T

50. Pagamento antecipado [ ]

CHN: (Yù Fù Kuăn)

ING: Advanced payment

51. Peso bruto [ ]

CHN: (Máo Zhòng)

ING: Gross weight

52. Peso líquido [ ]

CHN: (Jìng Zhòng)

ING: Net weight

53. Recibo de cais [ ]

CHN: (Jí Zhuāng Xiāng Chăng Shōu Jù)

ING: Dock receipt - D/R

54. Remessa [ ] 
CHN: (Huì Kuăn)

ING: Remittance

55. Representante de venda no estrangeiro [

CHN: $\quad$ (Hǎi Wài Xiāo Shòu Dài Lǐ)

ING: Foreign sales agent

56. Romaneio [ ]

CHN: : (Zhuāng Xiāng Dān)

ING: Packing list

57. Saque [ ]

CHN: (Huì Piào)

ING: Draft / bill of exchange

58. Seguro de exportação [ ]

CHN: (Chū Kǒu Băo Xiăn)

ING: Export insurance

59. Tara [ ]

CHN: (Pí Zhòng)

ING: Tara / Tare weight 
60. Tarifas aduaneiras [ ]

CHN: (Guān Shuì)

ING: Customs duty

61. Transferência telegráfica [ ]

CHN: (Diàn Huì)

ING: Telegraphic transfer $-\mathrm{T} / \mathrm{T}$

CABLE TELEX

SWIFT "T

$/ T^{\prime \prime}$

62. Transportador [ ]

CHN: (Chéng Yùn Rén)

ING: Carrier

63. Transporte e seguro pagos até - porto de embarque indicado [ ] CHN: $\quad$ (Yù Fèi Băo Xiăn Fù Zhì)

ING: CIP - Carriage and insurance paid to (named port of destination)

2000

I

64. Transporte pago até - porto de embarque indicado [ ]

CHN: $\quad$ (Yù Fèi Fù Zhì) 
ING: CPT - Carriage paid to (named port of destination)

2000 


\section{CONSIDERAÇÕES FINAIS}

Desde a decisão, em março de 2005, de elaborar um glossário terminológico de comérico exterior como minha dissertação de mestrado, passei um ano coletando as unidades especializadas na área de comércio exterior e registrando-as nas fichas terminológicas. O trabalho foi difícil no início, por causa da falta de contato com especialistas de domínio comercial. Recolhi várias dicionários e livros da área de comércio exterior no chinês e no português, entre eles, dois dicionários monolíngües em português e um dicionário monolíngüe em chinês. Consegui localizar mais um dicionário de comércio exterior de chinês e inglês para referência. O problema é que no dicionário de português de comércio exterior, as definições de alguns termos são muito simples, apresentando às vezes só uma palavra. Isto causou dificuldades no momento de julgar se o termo em chinês corresponde exatamente ao termo em português. Além disso, surgiram termos que são únicos no próprio português ou no chinês. Para traduzir o significado na língua de chegada, tive que consultar os especialistas sobre o significado exato do termo.

Através da pesquisa terminológica bilingüe entre o chinês e o português, consegui adqurir um conhecimento geral tanto na teoria da Terminologia quanto na utilização de termos do comércio exterior. Na minha leitura inicial das obras teóricas de Terminologia de português, não achei as informações sobre a evolução e desenvolvimento da Terminologia de chinês, fui então procurar nos livros chineses relacionados a Terminologia e consegui traduzir e organizar uma breve história sobre a Terminologia na China. Com esta história, os terminólogos de português poderão ter um conhecimento básico sobre o desenvolvimento da Terminologia na China.

Além da teoria terminológica, apresentei no meu trabalho a macroestrutura e a microestrutura de um dicionário de chinês, o que pode ajudar os dicionaristas de português a conhecer a diferença entre o dicionário da língua indo-européia e o dicionário da língua de chinês e a estrutura de um dicionário de ideograma. 
Coloquei também no meu trabalho uma introdução sobre ensino de português na China e de chinês no Brasil, para os interessados ter uma noção sobre a situação de intercâmbio entre as duas línguas.

O glossário contém os principais termos do chinês e do português da área de comércio exterior. Os falantes das duas línguas podem consultar neste glossário o significado de um termo chinês no documento de comércio exterior e a equivalência na língua portuguesa, e vise-versa. Desse modo, os especialistas de comércio exterior do Brasil e da China podem entender os termos principais de outro sem interpretação da terceira língua, inglês. Os outros terminólogos podem desenvolver este glossário para um dicionário terminológico de comércio exterior, baseando na metodologia nesta dissertação.

Devido ao prazo do mestrado, ao conhecimento limitado na área de comércio exterior, e ao tamanho do trabalho, somente inclui na minha dissertação os termos mais freqüentes com definições confirmadas pelos especialistas. Neste campo de estudo entre chinês e português, ainda há muito mais para pesquisar, tanto na teoria quanto na prática. No futuro, pretendo enriquecer o glossário com mais termos e fazer uma obra terminológica mais completa e de maior precisão entre o chinês e o português. 


\section{REFERÊNCIAS BIBLIOGRÁFICAS}

\subsection{Obras de fundamentação}

ALPÍZAR Castillo, R. Como Hacer un Diccionario Científico Técnico? Buenos Aires, Memphis, 1997.

ALVES, I.M. Constituição da normalização terminológica no Brasil. São Paulo, FFLCH/Humanitas, 1996.

ALVES, I.M. Glossário de termos neológicos da economia. São Paulo, FFLCH/Humanitas, 1998.

AUBERT, F.H. Introdução à metodologia da pesquisa terminológica bilíngüe. São Paulo, Humanitas Publicações-FFLCH/USP,1996.

BARBOSA, M. A. "Considerações sobre a Estrutura e Funções da Obra Lexicolográfica: Metodologia, Tecnologia e Condições de Produção". Colóquio de Lexicologia e Lexicografia. Lisboa, Universidade Nova de Lisboa, 1999.

BARROS, L. A. Curso Básico de Terminologia. São Paulo, EDUSP, 2004.

BOULANGER, J. C. Convergências e divergências entre a lexicologia e a terminologia. Porto Alegre: UFRGS, 2001.

CABRÉ, M. T. La Terminología: Teoria, Metodologia, Aplicaciones. Barcelona, Editorial Antártida/Empúries, 1993.

"Una Nueva Teoría de la Terminología: de la Denominación a la Comunicación”. - La Terminología: Representación y Comunicación. Barcelona, IULA, 1999.

DUBUC, R. Manuel practique de terminologie. Montreal, Linguatech, 1985.

FINATTO, M. J. B. Temas de Terminologia. Porto Alegre/São Paulo, Editora da UFRGS/Humanitas, 2001.

GONG, Y. Histórico de trabalho terminológico de chinês. Jornal de Instituto de Ciências Sociais da China.

KRIEGER, M. da G. \& FINATTO, M. J. B. Introdução à terminologia - teoria \& prática. São Paulo, Contexto, 2004.

MATTAR, D. de G. Glossário de termos de marketing. Dissertação de mestrado. São Paulo, USP, 1999.

ORGANISATION INTERNACIONALE DE NORMALISATION.Terminologie - vocabulaire.Genebra,1990 (Norme Internacionale ISO 1087, 1990).

PAVEL, S. \& NOLET, D. Manual de Terminologia [on line]. Disponível na www.translationbureau.gc.ca Arquivo capturado em 1 de setembro de 2002.

REY, A. Le lexique: images et modèles. Du dictionnaire à la lexicologie. Paris, Librairie/Armand Colin, 1977.

TERRA, Ernani; DE NICOLA, José; MENÓN, Lorena Mariel. - 1001 Estrangeirismos de Uso Corrente em Nosso Cotidiano. São Paulo, Saraiva, 2003.

VAN HOOF, H. Os Tradutores e os Dicionários. Os Tradutores na História. São Paulo, Ática, 1998.

\subsection{Obras especializadas em comércio exterior}


HINKELMAN, E. G. Handbook of the Global Trade Community. $4^{\text {th }}$.Ed. Versão Chinesa Traduzida por LI, J. Beijing, Economic Science Press, 2002.

MIGLIAVACCA, P. N. Business dictionary - Dicionário de Termos de Negócios. São Paulo, Edicta, 2004.

VAZQUEZ, J. L. Dicionário de Termos de Comércio Exterior. São Paulo, Atlas, 2001.

Comércio Exterior Brasileiro. 7. ed. São Paulo: Atlas, 2004.

FILHO, E. G. Dicionário de Comércio Exterior e Câmbio. São Paulo, Saraiva, 2004.

WENG, F. X. Manual de Gráfico, Documentação e Certificados. Hangzhou, Editora de Universidade de Zhejiang, 2002.

XUE, Y. J., WANG, S. X. Dicionário Moderno de Comércio e Finanças. Beijing, Editora de Universidade de Economia e Comércio ao Exterior, 1996.

\subsection{Outras Obras}

ASSUNÇÃO, M. 30 Anos de Intercâmbio Cultural. Revista Parceria. Edição Especial 30 Anos. São Paulo, Câmara Brasil-China de Desenvolvimento Econômico, 2004.

FERREIRA, A. B. H. Novo Dicionário da Língua Portuguesa. $2^{\mathrm{a}}$ ed. Rio de Janeiro, Nova Fronteira, 1986.

HUANG, Q. C. A Posição Dominante da China na Globalização Mundial - do Meio de Século XVI ao Começo de Século XIX. Guangzhou, Zhongshan Universidade/Faculdade da História, 2004.

HOUAISS, A., VILLAR, M. S. Dicionário Houaiss da língua portuguesa. Rio de Janeiro, Objetiva. 2001.

Revista Visão da China. Edição Especial de 2004. São Paulo, Câmara de Comércio e Indústria Brasil-China. 2004. P. 18-22.

Revista Negócios com a China. Edição Especial 2005. Rio de Janeiro, Instituto de Cooperação Internacional, 2005.

WANG, S.Y.; LU, Y.B. Dicionário Conciso Chinês-Português. Shanghai, Editora de Educação de Língua Estrangeira de Shanghai, 1997.

ZHOU, H.J.; WANG, Z.Y.; ZHAO, H.L.; CUI, W.X. Dicionário Conciso PortuguêsChinês. Beijing, Editora Comercial, 1995. 